\section{Pacific Northwest}

National Laboratory

Operated by Battelle for the

U.S. Department of Energy

\title{
Existing Evidence for the Fate of Neptunium in the Yucca Mountain Repository
}

\author{
J. I. Friese \\ E. C. Buck \\ B. K. McNamara \\ B. D. Hanson \\ S. C. Marschman
}

June 2003

Prepared for the U.S. Department of Energy under Contract DE-AC06-76RL01830 


\title{
DISCLAIMER
}

This report was prepared as an account of work sponsored by an agency of the United States Government. Neither the United States Government nor any agency thereof, nor Battelle Memorial Institute, nor any of their employees, makes any warranty, express or implied, or assumes any legal liability or responsibility for the accuracy, completeness, or usefulness of any information, apparatus, product, or process disclosed, or represents that its use would not infringe privately owned rights. Reference herein to any specific commercial product, process, or service by trade name, trademark, manufacturer, or otherwise does not necessarily constitute or imply its endorsement, recommendation, or favoring by the United States Government or any agency thereof, or Battelle Memorial Institute. The views and opinions of authors expressed herein do not necessarily state or reflect those of the United States Government or any agency thereof.

\author{
PACIFIC NORTHWEST NATIONAL LABORATORY \\ operated by \\ BATTELLE \\ for the \\ UNITED STATES DEPARTMENT OF ENERGY \\ under Contract DE-ACO6-76RLO183O
}

This document was printed on recycled paper. 


\title{
Existing Evidence for the Fate of Neptunium in the Yucca Mountain Repository
}

\author{
J. I. Friese \\ E. C. Buck \\ B. K. McNamara \\ B. D. Hanson \\ S. C. Marschman
}

June 2003

Prepared for the U.S. Department of Energy under Contract DE-AC06-76RL01830

Pacific Northwest National Laboratory

Richland, Washington 99352 


\section{Summary}

Neptunium, because of its long half life, is an element of long-term interest to the Yucca Mountain repository. The fate of neptunium under repository settings is unknown. This report provides a review and new interpretation of past tests on commercial spent nuclear fuel and experimental evidence on the fate of neptunium.

Tests on commercial spent nuclear fuel preformed previously at Pacific Northwest National Laboratory (PNNL) used a "bathtub" setup by immersing spent fuel in either deionized water or a groundwater typical of those at Yucca Mountain. The main goal of the tests was to determine the different concentrations of radionuclides in solution with different types of cladding defects. Neptunium was not the focus of these tests, and the tests were not designed to study neptunium. Drip tests performed at Argonne National Laboratory (ANL) are unsaturated tests that drip water at different rates on spent fuel. Relatively new tests at ANL are examining the corrosion of Np-doped $\mathrm{U}_{3} \mathrm{O}_{8}$ in humid air at various temperatures.

This review concludes that all tests reported here have analytical problems (i.e., relatively high detection limits for $\mathrm{Np}$ ) and have been configured such that they limit the ability to interpret the available neptunium data.

Past tests on spent nuclear fuel do not unambiguously describe neptunium chemistry as there are multiple mechanisms that may explain the observed behavior in each test. One apparently major shortcoming of most tests is that the extent of fuel reaction was limited by the amount of oxygen present in the system. Further detailed studies under repository-relevant conditions, which include the assumption of a constant 20 percent oxygen atmosphere, are needed to provide the data necessary for the development and validation of models used to predict the long-term fate of neptunium and other radionuclides at Yucca Mountain. 


\section{Acronyms}

$\begin{array}{ll}\text { ANL } & \text { Argonne National Laboratory } \\ \text { CSNF } & \text { Commercial Spent Nuclear Fuel } \\ \text { DIW } & \text { Deionized Water } \\ \text { EDS } & \text { Energy Dispersive Spectroscopy } \\ \text { EELS } & \text { Energy Electron-Loss Spectroscopy } \\ \text { EMSP } & \text { Environmental Management Science Program } \\ \text { EXAFS } & \text { Extended X-Ray Absorption Fine Structure } \\ \text { HBR } & \text { H. B. Robinson (Unit 2) } \\ \text { NIST } & \text { National Institute for Standards and Technology } \\ \text { NRC } & \text { U.S. Nuclear Regulatory Commission } \\ \text { SEM } & \text { Scanning Electron Microscopy } \\ \text { SNF } & \text { Spent Nuclear Fuel } \\ \text { TP } & \text { Turkey Point (Unit 3) } \\ \text { TSPA } & \text { Total System Performance Assessment } \\ \text { XANES } & \text { X-Ray Diffractometry } \\ \text { XRD } & \text { Strotion Near Edge Structure } \\ & \end{array}$




\section{Contents}

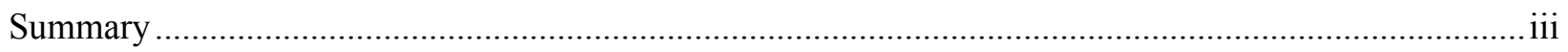

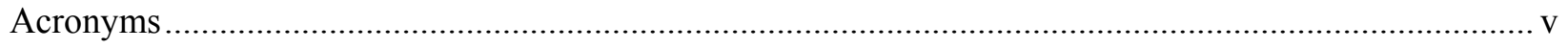

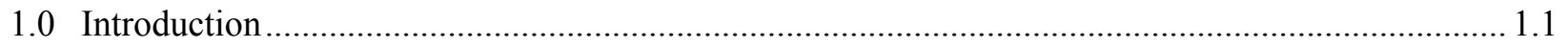

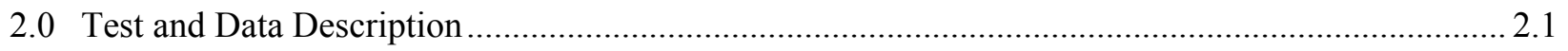

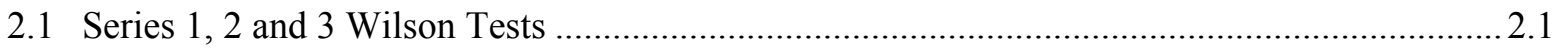

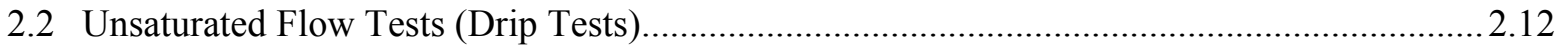

2.3 Progress Report on Dissolved Concentration Limits: Neptunium in Alteration Phases ......... 2.18

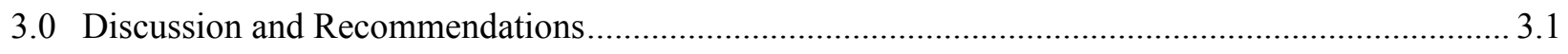

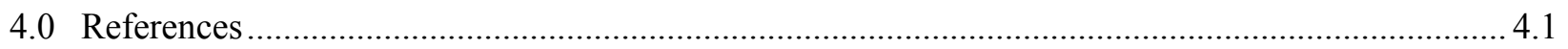

\section{Figures}

1.1. Calculated Speciation of Uranium and Neptunium from Published Stability Constants.................. 1.4

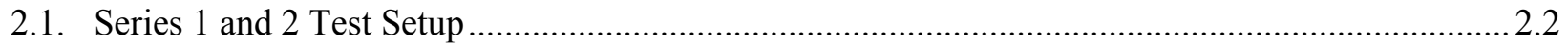

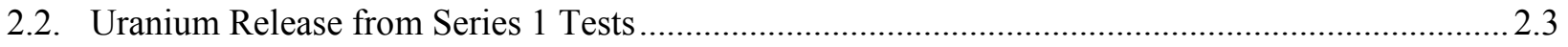

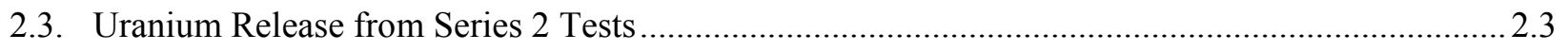

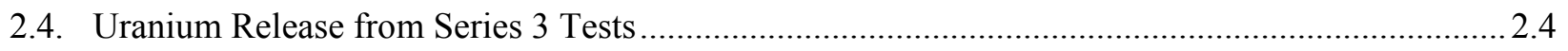

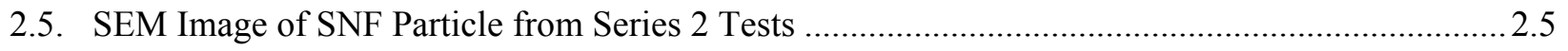

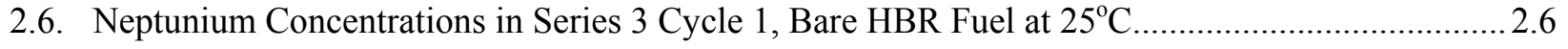

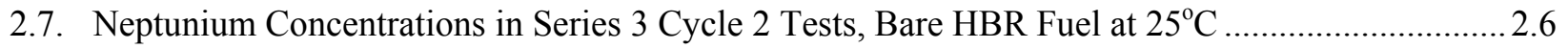

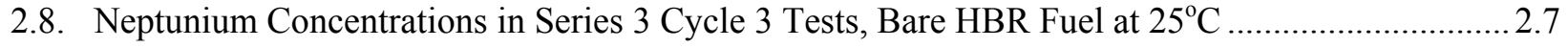

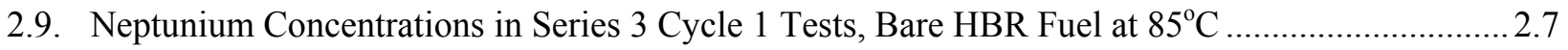

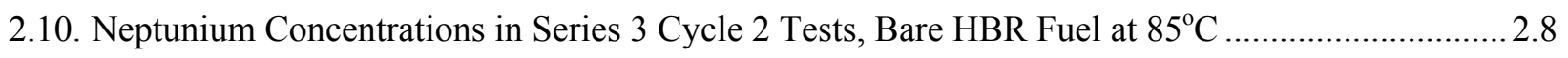


2.11. Neptunium Concentrations in Series 3 Cycle 3 Tests, Bare HBR Fuel at $85^{\circ} \mathrm{C}$

2.12. Neptunium Concentrations in Series 3 Cycle 1 Tests, Bare TP Fuel at $85^{\circ} \mathrm{C}$.

2.13. Neptunium Concentrations in Series 3 Cycle 2 Tests, Bare TP Fuel at $85^{\circ} \mathrm{C}$.

2.14. Neptunium Concentrations in Series 3 Cycle 3 Tests, Bare TP Fuel at $85^{\circ} \mathrm{C}$.

2.15. Neptunium Concentrations in ANL High Drip Rate Tests

2.16. Neptunium Concentrations in ANL Low Drip Rate Tests.

2.17. Neptunium Concentrations in ANL Vapor Tests.

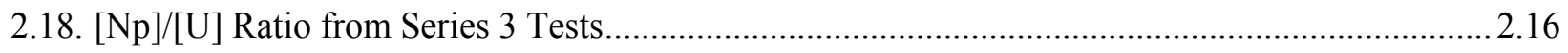

2.19. $[\mathrm{Np}] /[\mathrm{U}]$ Ratio from ANL High Drip Rate Tests................................................................2.16

2.20. $[\mathrm{Np}] /[\mathrm{U}]$ Ratio from ANL Low Drip Rate Tests ............................................................... 2.17

2.21. Cumulative Release of Neptunium and Uranium from High Drip Rate Tests .......................... 2.17

2.22. Cumulative Release of Neptunium and Uranium from Low Drip Rate Tests ..............................2.18

\section{Tables}

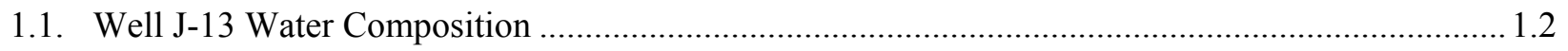

1.2. Averaged Concentrations of ${ }^{237} \mathrm{~Np}\left(\right.$ in $\mathrm{mol} \mathrm{L}^{-1}$ ) as a Function of $\mathrm{pH}$ and Temperature as Measured from Oversaturation (after 450 days equilibration) and Undersaturation (after 151 days equilibration)... 


\subsection{Introduction}

The U.S. Department of Energy plans to permanently store commercial spent nuclear fuel (CSNF) at a proposed deep underground repository to be constructed under Yucca Mountain in Nevada. The fate of neptunium and other radionuclides is important for predicting dose in the total system performance assessment (TSPA) for the proposed repository (Andrews et al. 1994). As part of the characterization, risk assessment considers the consequences of water intrusion into the repository. The rate of groundwater flow through the waste is expected to be sufficiently low to permit saturation with solubilitycontrolled radionuclides; therefore, solubility and speciation data define the source term for transport and retardation processes. The technical position of the U.S. Nuclear Regulatory Commission (NRC) requires that if radionuclide solubility is used as a factor in limiting radionuclide release, solubility experiments must be designed to use site-specific conditions (Brooks and Corrado 1984).

For meaningful interpretation of solubility data, detailed knowledge of the nature of the solubilitycontrolling solid phase along with the concentration and composition of solution species is required. This requirement for neptunium is problematic because of the lack of understanding of neptunium-controlling phases. Because neptunium is of long-term concern (half life of 2.14 million years) for the emplacement of nuclear waste, it is necessary to determine both the short- and long-term fate of neptunium and, for early-failed packages, its predecessors (i.e., plutonium and americium) under repository conditions.

It is generally accepted that the water chemistry in contact with the spent nuclear fuel (SNF) will be of low ionic strength and similar in composition to J-13 water from the Yucca Mountain Site, and thus most past testing has been done using this type of water. The water composition of J-13 water is summarized in Table 1.1. Several components of J-13 water may affect the chemistry of neptunium. The carbonate, silicate, and cations present in the water will play an important role in the fate of neptunium released from SNF forming various complexes that will alter its solubility. This water in contact with the inventory of SNF will determine the mobility of neptunium in the Yucca Mountain environment.

The solubility of neptunium in J-13 groundwater has been reported by several researchers (Efurd et al. 1998; Nitsche et al. 1992a; Nitsche et al. 1992b). The average concentrations of neptunium as a function of $\mathrm{pH}$ and temperature are summarized in Table 1.2 using simplified systems. The neptunium concentration under most credible repository conditions appears to be about $10^{-5} \mathrm{M}$ in both undersaturated (no precipitate observed) and oversaturated (neptunium solid phase observed) studies. In the oversaturated studies, the neptunium solid phase identified in unaltered $\mathrm{J}-13$ water was $\mathrm{Np}_{2} \mathrm{O}_{5}$. If the ionic strength is increased, then various sodium neptunyl(V) carbonate solids form.

These studies indicate that when neptunium $(\mathrm{V})$ is placed in J-13 type waters, the maximum concentration of neptunium in solution is about $10^{-5} \mathrm{M}$ if it is controlled by the solubility of the $\mathrm{Np}_{2} \mathrm{O}_{5}$ solid phase. However, the combined waste form and waste package present in the repository will include large amounts of uranium, iron, and various other metals that may influence neptunium behavior. 
Table 1.1. Well J-13 Water Composition

\begin{tabular}{|l|c|}
\hline Species & Concentration (mM) \\
\hline $\mathrm{Na}^{+}$ & 1.96 \\
\hline $\mathrm{K}^{+}$ & 0.136 \\
\hline $\mathrm{Li}^{+}$ & 0.009 \\
\hline $\mathrm{Ca}^{2+}$ & 0.29 \\
\hline $\mathrm{Mg}^{2+}$ & 0.072 \\
\hline $\mathrm{Mn}^{2+}$ & 0.00002 \\
\hline $\mathrm{Fe}^{2+/ 3+}$ & 0.0008 \\
\hline $\mathrm{Al}^{3+}$ & 0.001 \\
\hline $\mathrm{pH}^{2+}$ & 7.0 \\
\hline $\mathrm{F}^{-}$ & 0.11 \\
\hline $\mathrm{Cl}^{-}$ & 0.18 \\
\hline $\mathrm{NO}_{3}{ }^{-}$ & 0.16 \\
\hline $\mathrm{SO}_{4}{ }^{2-}$ & 0.19 \\
\hline $\mathrm{SiO}_{2}$ & 1.07 \\
\hline $\mathrm{Alkalinity}^{2}$ & $2.3 \mathrm{mequiv} / \mathrm{L}$ \\
\hline Total carbonate & 2.81 \\
\hline $\mathrm{E}_{\mathrm{h}}$ & $700 \mathrm{mV}$ \\
\hline
\end{tabular}

Table 1.2. Averaged Concentrations of ${ }^{237} \mathrm{~Np}\left(\right.$ in $\mathrm{mol} \mathrm{L}^{-1}$ ) as a Function of $\mathrm{pH}$ and Temperature as Measured from Oversaturation (after 450 days equilibration) and Undersaturation (after 151 days equilibration)

\begin{tabular}{|c|c|c|c|}
\hline & pH 6 & pH 7 & pH 8.5 \\
\hline \multicolumn{4}{|c|}{$25^{\circ} \mathrm{C}$} \\
\hline Oversaturation $^{(\mathrm{a})}$ & $(6.5 \pm 1.1) \times 10^{-4}$ & $(3.1 \pm 0.2) \times 10^{-5}$ & $(1.5 \pm 0.6) \times 10^{-5}$ \\
\hline Undersaturation $^{(\mathrm{a})}$ & $(6.5 \pm 1.0) \times 10^{-4}$ & $(2.9 \pm 0.7) \times 10^{-5}$ & $(1.5 \pm 0.3) \times 10^{-5}$ \\
\hline Undersaturation $^{(\mathrm{b})}$ & $(5.3 \pm 0.1) \times 10^{-3}$ & $(1.3 \pm 0.3) \times 10^{-4}$ & $(4.4 \pm 0.7) \times 10^{-3}$ \\
\hline \multicolumn{4}{|c|}{$60^{\circ} \mathrm{C}$} \\
\hline Oversaturation $^{(a)}$ & $(9.4 \pm 1.2) \times 10^{-4}$ & $(1.6 \pm 0.6) \times 10^{-5}$ & $(1.7 \pm 0.9) \times 10^{-5}$ \\
\hline \multicolumn{4}{|l|}{ Undersaturation $^{(\mathrm{a})}$} \\
\hline Undersaturation $^{(\mathrm{b})}$ & $(6.4 \pm 0.4) \times 10^{-3}$ & $(9.8 \pm 1.0) \times 10^{-4}$ & $(1.0 \pm 0.1) \times 10^{-5}$ \\
\hline \multicolumn{4}{|c|}{$90^{\circ} \mathrm{C}$} \\
\hline Oversaturation $^{(a)}$ & $(9.1 \pm 1.8) \times 10^{-4}$ & $(8.6 \pm 2.3) \times 10^{-6}$ & $(5.8 \pm 2.5) \times 10^{-6}$ \\
\hline Undersaturation $^{(\mathrm{a})}$ & $(8.7 \pm 0.9) \times 10^{-4}$ & $(9.3 \pm 1.9) \times 10^{-6}$ & $(5.9 \pm 2.1) \times 10^{-6}$ \\
\hline Undersaturation $^{(b)}$ & $(1.2 \pm 0.1) \times 10^{-3}$ & $(1.5 \pm 0.4) \times 10^{-4}$ & $(8.9 \pm 0.4) \times 10^{-5}$ \\
\hline \multicolumn{4}{|c|}{$\begin{array}{l}\text { (a) Efurd et al. 1998. } \\
\text { (b) Lemire 2001; Czerwinski et al. } 2001 .\end{array}$} \\
\hline
\end{tabular}

Neptunium is expected to be in the tetravalent state in the SNF waste form. For neptunium to be mobile in the environment, it would need to be oxidized from the tetravalent state to pentavalent or hexavalent as these two states are several orders of magnitude more soluble than the tetravalent state (Lemire 2001). This relation between mobility and the oxidation state of neptunium is important. If it is not oxidized 
from the SNF matrix and remains left behind, then the mobility should be limited because of the poor solubility of tetravalent neptunium (i.e., $\mathrm{NpO}_{2}$ ). However, if the oxidation conditions (either from oxygen, radiolysis, or a combination of the two) can oxidize neptunium, then the potential for neptunium release will be more important.

Several factors affect the mobility of neptunium after release from the SNF matrix. The chemical speciation of both neptunium and uranium will depend on the chemistry of the groundwater. For example, Figure 1.1 is the calculated speciation of both uranium and neptunium in J-13 water. The difference in speciation will make the neptunium mobility in the environment different than uranium, potentially causing preferential release. The speciation of neptunium is also dependent on Eh and temperature (Czerwinski et al. 2001). The mobilization of neptunium by radiolysis is also unknown and may be important. The chemical behavior, oxidation response, and release characteristics under repository conditions are of interest to determine the fate of neptunium and its ultimate impact on dose calculations. 


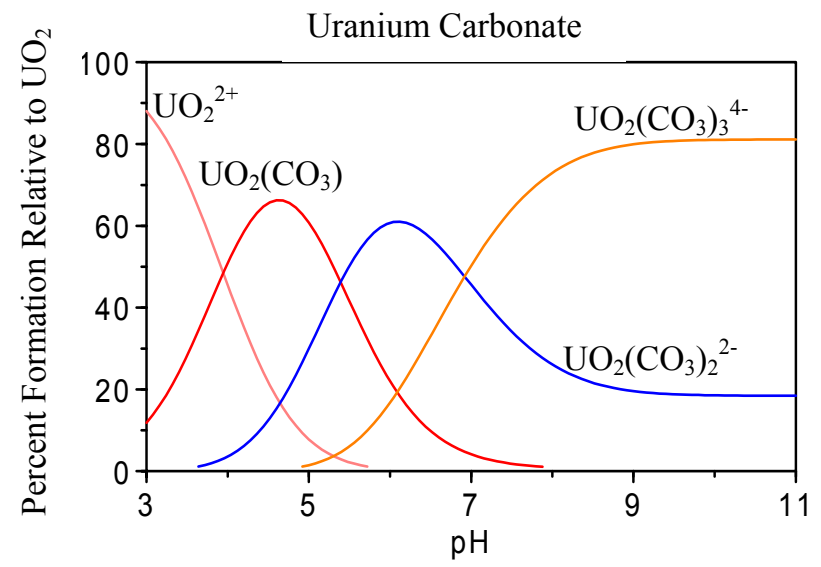

1a. $10^{-3} \mathrm{M}$ Uranium, $2.81 \mathrm{mM}$ Carbonate

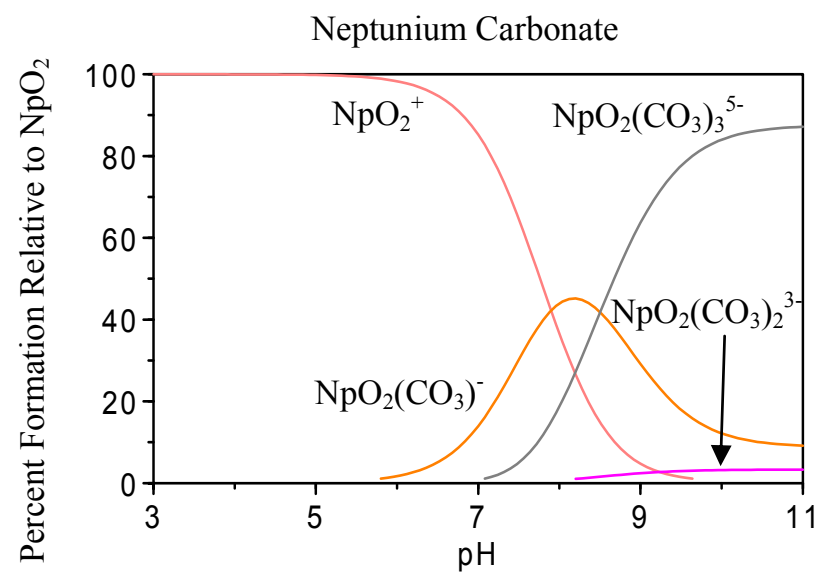

1b. $10^{-3} \mathrm{M}$ Neptunium, $2.81 \mathrm{mM}$ Carbonate

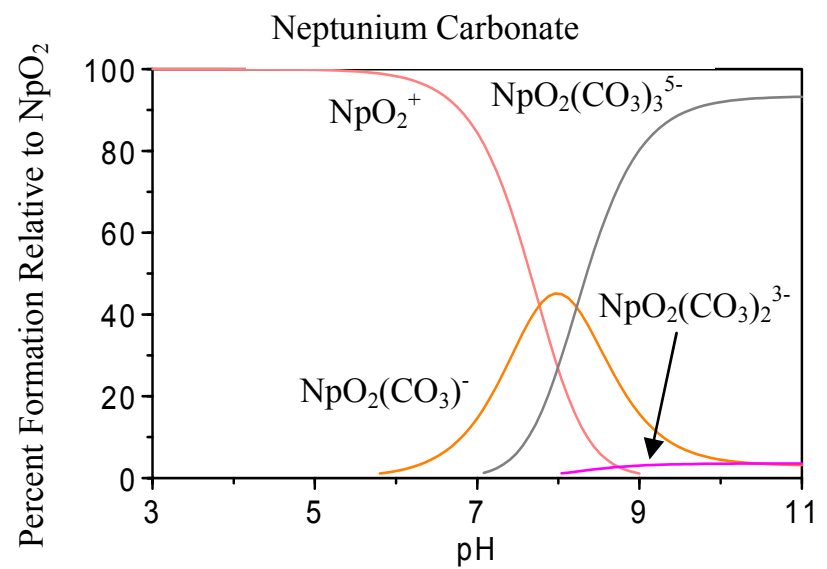

1c. $10^{-8} \mathrm{M}$ Neptunium, $2.81 \mathrm{mM}$ Carbonate

Figure 1.1. Calculated Speciation of Uranium and Neptunium from Published Stability Constants (National Institute for Standards and Technology [NIST] Standard Reference Database 46, Version 6.0, NIST Critically Selected Stability Constants of Metal Complexes) 


\subsection{Test and Data Description}

\subsection{Series 1, 2 and 3 Wilson Tests}

Wilson studied the use of SNF in batch or "bathtub" experiments in both deionized water (DIW) and J-13 water (Wilson 1987a, 1987b, 1990). These experiments used SNF from two different pressurized water reactors. One fuel was from H.B. Robinson Unit 2 (HBR), which had an estimated burnup of 30 $\mathrm{MWD} / \mathrm{kg} \mathrm{U}$. This fuel is also referred to as ATM-101 (Barner 1984). The second fuel type is from the Turkey Point Unit 3 (TP) reactor and has an estimated burnup of $27 \mathrm{MWD} / \mathrm{kg} \mathrm{U}$. Both fuels have very similar decay times and initial enrichments and thus have very similar radiation fields. The most significant difference is that the HBR fuel has an $\approx 6$ - $\mu \mathrm{m}$ grain size compared to the $\approx 25$ - $\mu \mathrm{m}$ grain size of the Turkey Point fuel. The radionuclide inventory was calculated using ORIGEN2. Radiochemical analysis of both fuels was also performed to determine the experimental inventory of some radionuclides.

A diagram of the Series 1 and 2 experimental setup is shown in Figure 2.1. There were three different types of tests. Series 1 involved the immersion of bare spent fuel (about $40 \mathrm{~g}$ ) or spent fuel in cladding with various defects in DIW at room temperature. The solution concentration of radionuclides at various time intervals was measured. Series 2 was similar to Series 1, including the use of a fused quartz vessel and inclusion of quartz rods, but used J-13 water instead of DIW and used either $\approx 80 \mathrm{~g}$ of HBR SNF or 27 $\mathrm{g}$ of TP SNF. Series 3 used J-13 water, but the test vessels were sealed stainless steel instead of the fused quartz vessels used in Series 1 and 2 and did not include the quartz rods. Series 3 also was performed at both ambient $\left(\approx 25^{\circ} \mathrm{C}\right)$ and elevated $\left(\approx 85^{\circ} \mathrm{C}\right)$ temperature, whereas the first two series were performed only at ambient temperature. Series 3 also used about $80 \mathrm{~g}$ of SNF per experiment.

Each series was composed of several cycles. A cycle consisted of replacing all of the water (either DIW or J-13) and using either a new or cleaned reaction vessel. Reaction vessels were cleaned by acid stripping to remove all sorbed radionuclides. The neptunium concentration at the beginning of a cycle was usually substantially lower than at the end of the previous cycle. Because the fuel was not changed between cycles, the drop in concentration indicates that a single phase is not controlling the total solution concentration. This may be an indication that the amount of neptunium in solution is controlled by how much fuel is reacting during each cycle. It appears that the extent of matrix reaction is decreasing in each subsequent cycle.

The Series 1 experiments indicate that neptunium may show preferential release relative to uranium, plutonium, curium and americium. The report concludes that this is contrary to expectations of congruent release of uranium and neptunium (Wilson 1987a). Because of relatively high analytical detection limits and the small amount of neptunium present in spent fuel, neptunium was often below detection limits for many of the samples taken. A congruent release of $U$ and $\mathrm{Np}$ cannot be readily determined from the Series 1 tests. More neptunium was detected in Series 3, and congruent release was confirmed. The uranium concentration in solution was observed past 200 days as shown in Figure 2.2. This may be caused by the formation of solubility-controlling secondary corrosion phases such as schoepite or uranyl silicates. However, no attempt was made to identify the alteration products in the Series 1 tests. 


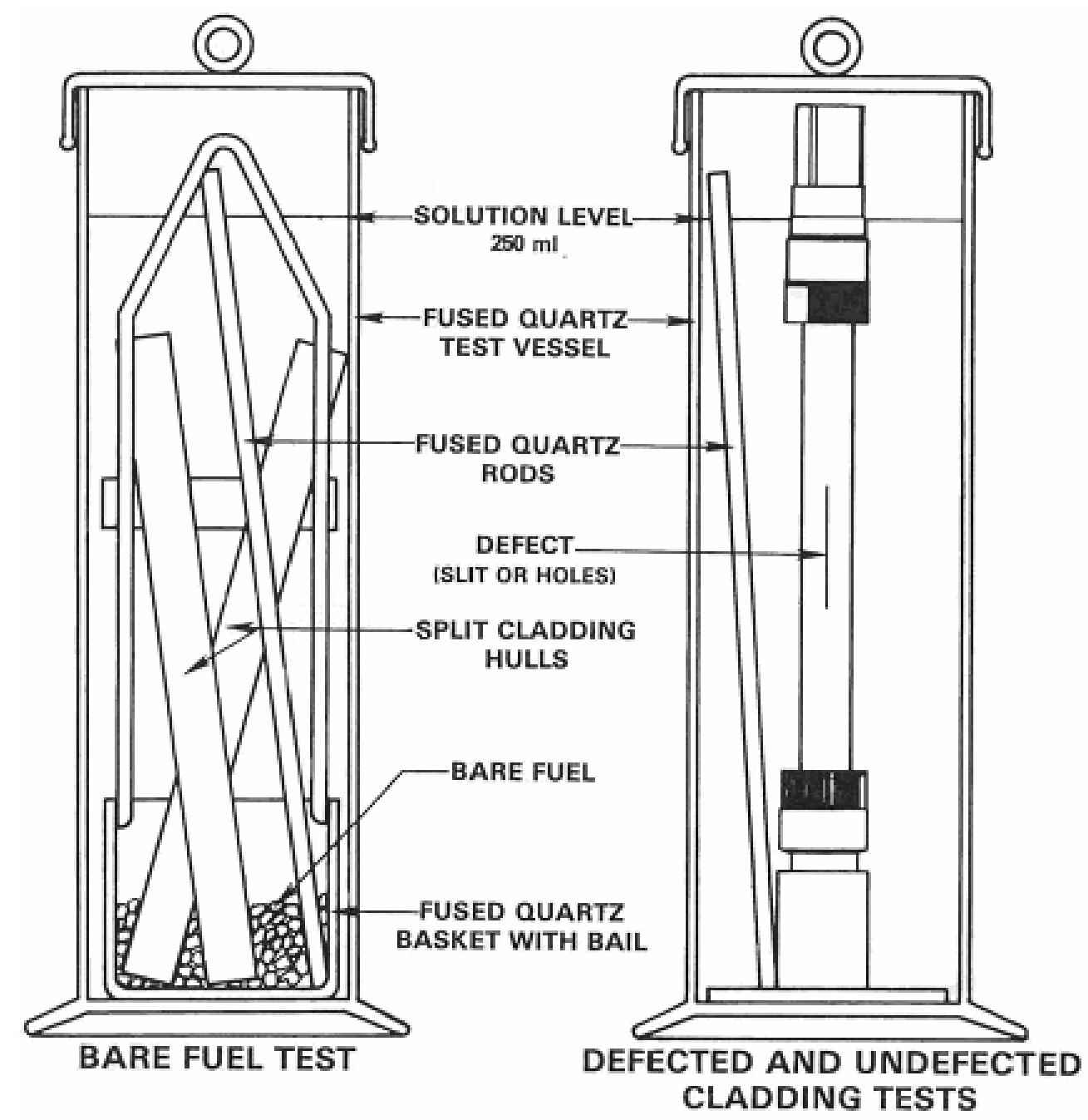

Figure 2.1. Series 1 and 2 Test Setup

The Series 2 experiments also experienced low neptunium release from the fuel, which made analytical detection a problem. However, from available data from the bare fuel tests, uranium and neptunium did release congruently as expected. Figure 2.3 is a plot of the uranium concentrations in solution as functions of time and cladding defect. The higher uranium concentrations observed in J-13 water relative to DIW is expected because of carbonate complexation, which increases the uranium concentration in solution. A second observation from Figure 2.3 is that all three tests did not reach the same uranium concentrations and, in fact, differ by more than three orders of magnitude. If the uranium concentration in solution was controlled by the same solid phase, and the system has reached equilibrium, then the uranium concentrations should be identical in all three tests. Because it appears that at least a pseudoequilibrium concentration was achieved in each of the three tests, then either each sample is controlled by a different phase or the concentration was simply limited in each case by extremely slow matrix dissolution. It is possible, however, that formation of a controlling phase is sufficiently slow that at later times, the uranium concentrations in the three tests would converge, as observed in Figure 2.2 as this phase forms. It is clear that the type of defect in the cladding affects the total uranium concentration. This result indicates that transport issues are important. 


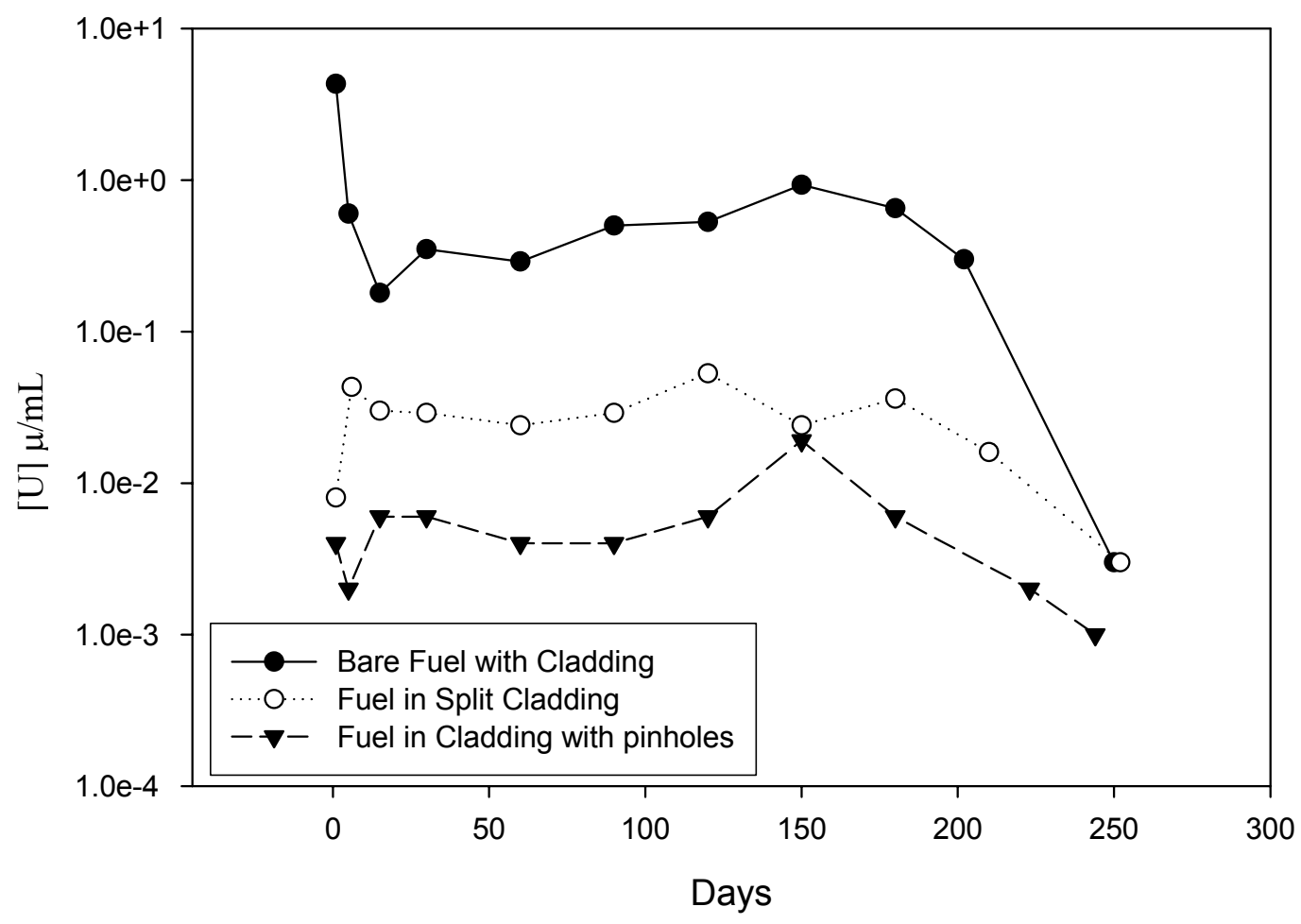

Figure 2.2. Uranium Release from Series 1 Tests

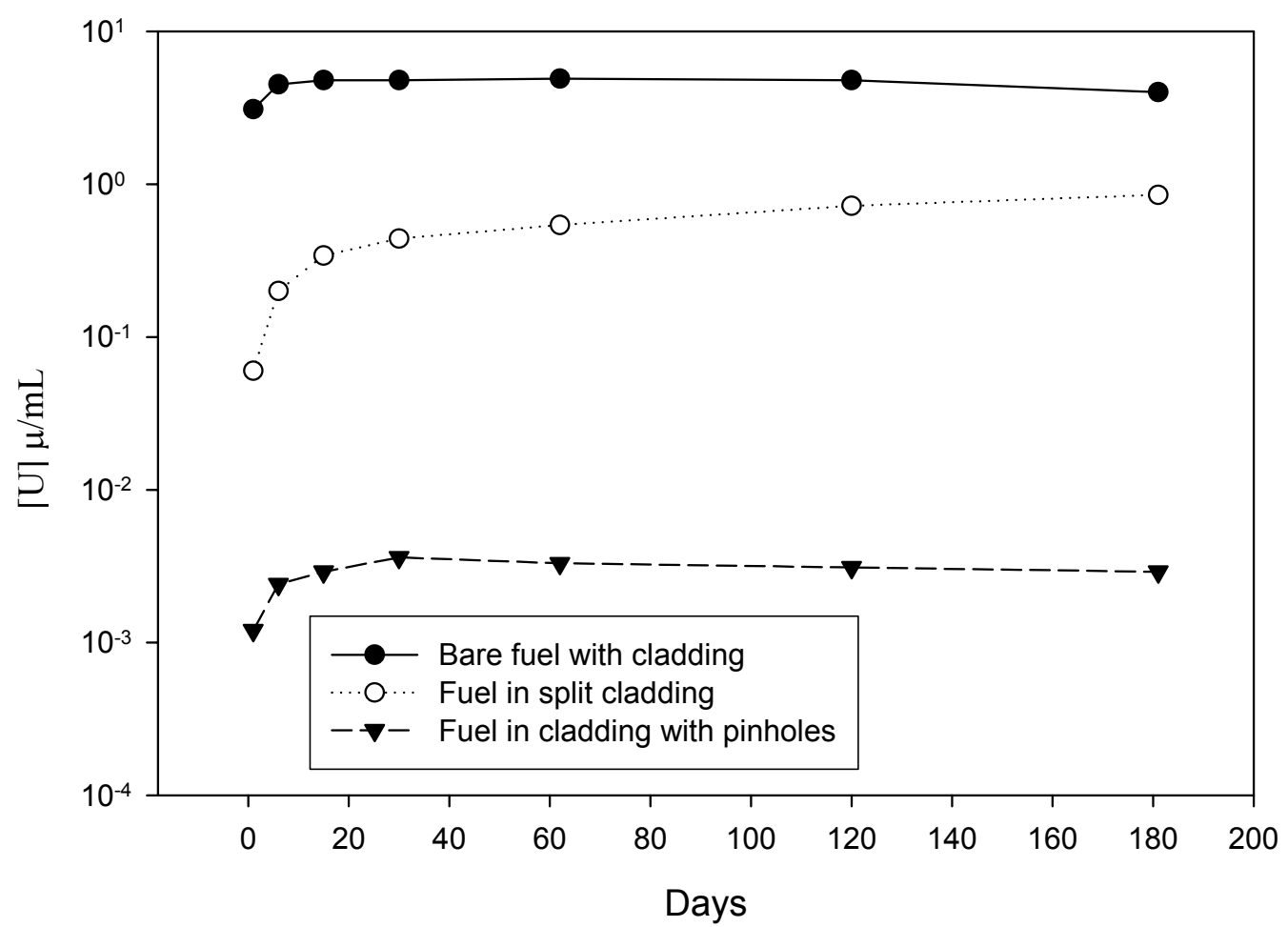

Figure 2.3. Uranium Release from Series 2 Tests 
The Series 3 experiments had several overall observations. The actinide concentrations reached steady state levels in bare fuel tests. This was attributed to the achievement of a steady state between fuel dissolution and secondary-phase formation or other mechanism such as sorption that is not controlled by pure phase solubility. Uranium secondary phases (uranyl silicates) were observed by X-ray diffractometry (XRD) at $85^{\circ} \mathrm{C}$. Figure 2.4 is the uranium concentration of the solutions at various times. Secondary phases of the other actinides were not identified. The uranium concentrations observed are consistent with uranyl silicate phases controlling the solubility.

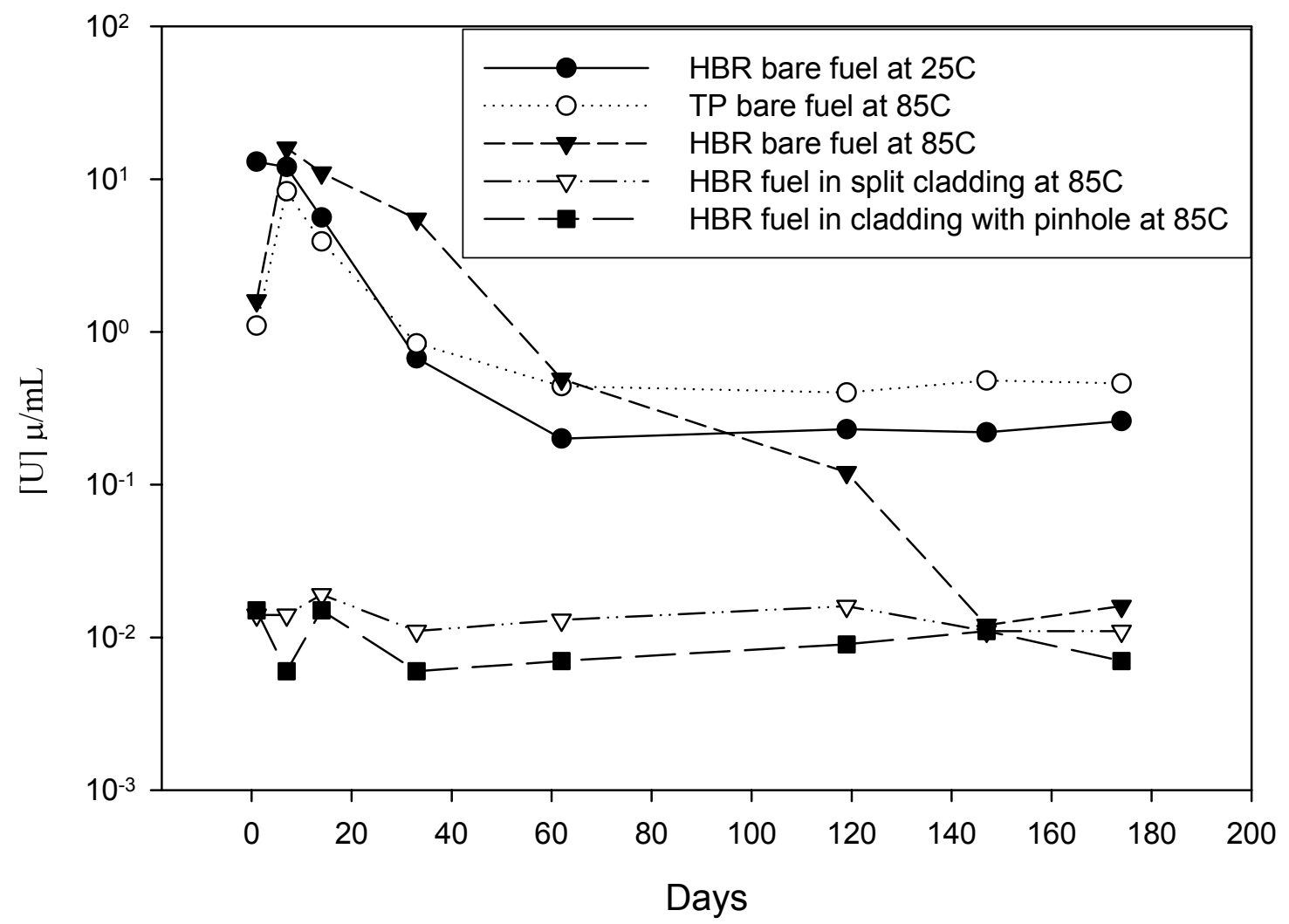

Figure 2.4. Uranium Release from Series 3 Tests

The significant decrease in the uranium concentration in the $85^{\circ} \mathrm{C}$ HBR bare fuel test was attributed to corrosion of the specimen basket that resulted in the release of iron, a reducing agent. Reduction of other actinides, such as neptunium, and fission products will also occur under such conditions. This reduction can readily result in a greater than order of magnitude decrease in release from the waste package, considering the large iron-to-uranium ratio in the repository. Neptunium solution concentrations are known to depend on Eh, and the unknown Eh gradient in Series 1, 2, and 3 tests may limit interpretation.

All three series indicated changes in radionuclide concentrations with filter size and cladding defect type. Plutonium, americium, and curium showed different concentrations, depending on whether the sample was filtered. Uranium and neptunium did not show a large change when filtered, indicating that these elements were not colloidal, which is consistent with carbonate complexation. Figures 2.2, 2.3, and 2.4 clearly indicate a dramatic dependence on uranium concentrations based on the type of defect in the cladding as discussed earlier. A scanning electron microscopy (SEM) image of an SNF particle collected 
from the filtrate in the Series 2 tests is shown in Figure 2.5. The report noted that the particle was covered by a silica gel due the excess silica in the system. The effect on neptunium concentrations from the formation of this silica gel is unknown, but it may serve as a transport barrier that slows down the dissolution of the SNF matrix.

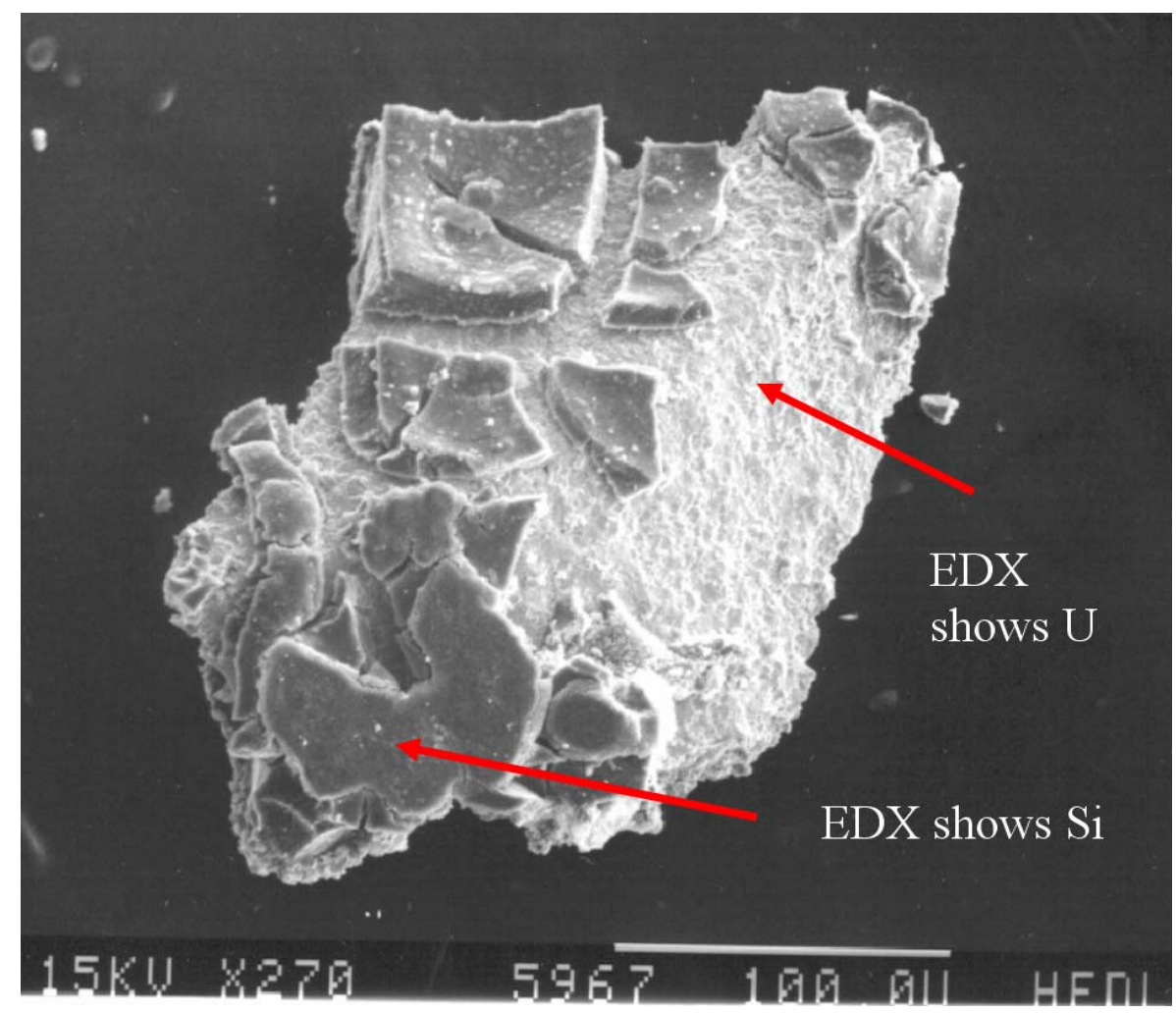

Figure 2.5. SEM Image of SNF Particle from Series 2 Tests

There are various insights on the fate of neptunium indicated from Series 1,2, and 3 tests. There is a general trend of decreasing neptunium concentrations with time in all cycles (as shown in Figures 2.6 through 2.14. Note the change in scale between each cycle.). As neptunium is released from the fuel, the lowering of the total concentration with time indicates that neptunium is going into a "sink" that controls the dissolved concentration. Secondly, the total solution concentration of neptunium is typically very low (ranging from $5 \times 10^{-10} \mathrm{M}$ to $8 \times 10^{-8} \mathrm{M}$ ). It is of note there is not a dramatic change in neptunium concentration between DIW and J-13 water or the type of fuel used. However, as with uranium, the concentrations of neptunium in each subsequent cycle are typically lower than the concentration at the end of the previous cycle. This seems to indicate that the dissolution of the SNF matrix is limited. 


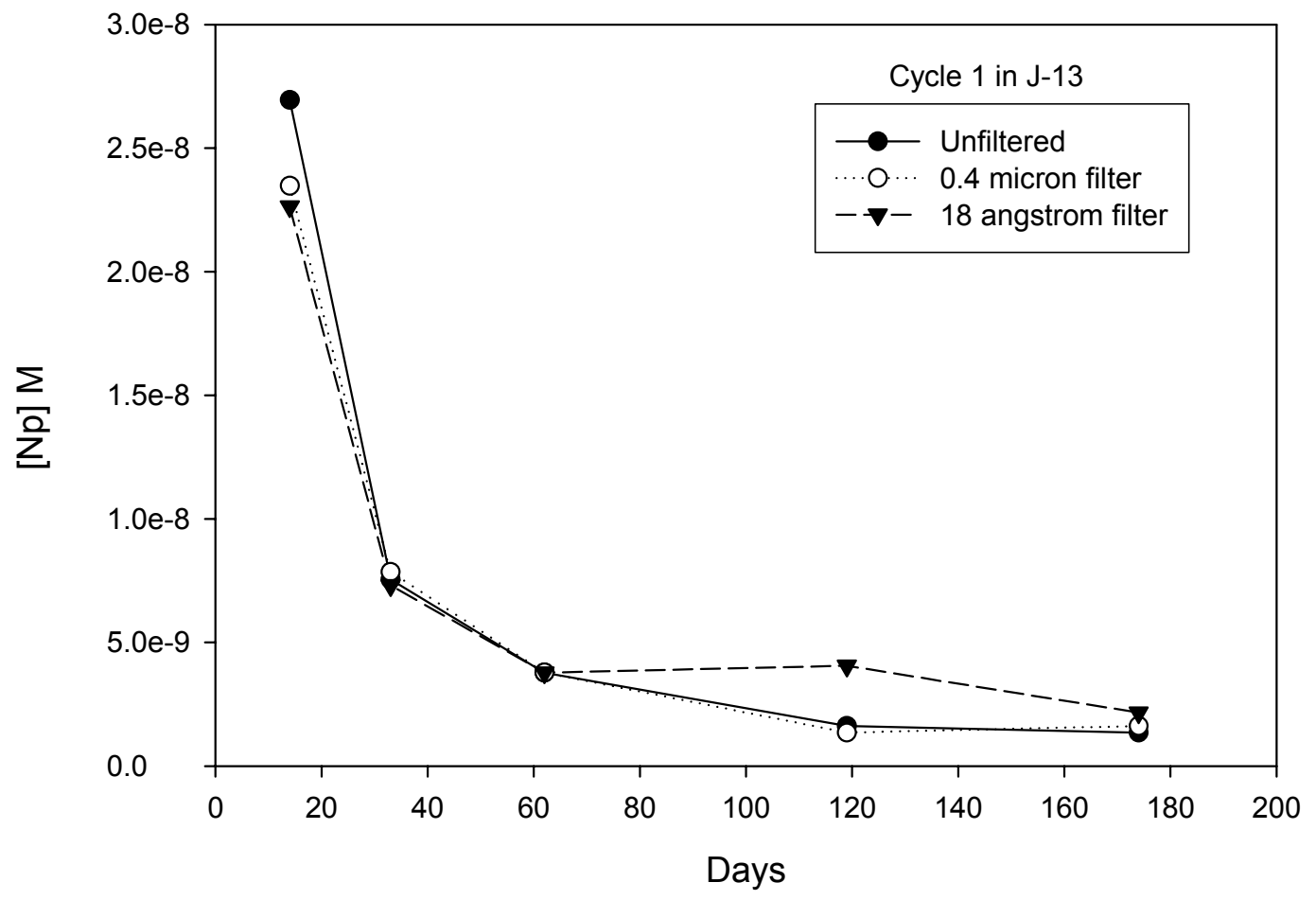

Figure 2.6. Neptunium Concentrations in Series 3 Cycle 1, Bare HBR Fuel at $25^{\circ} \mathrm{C}$

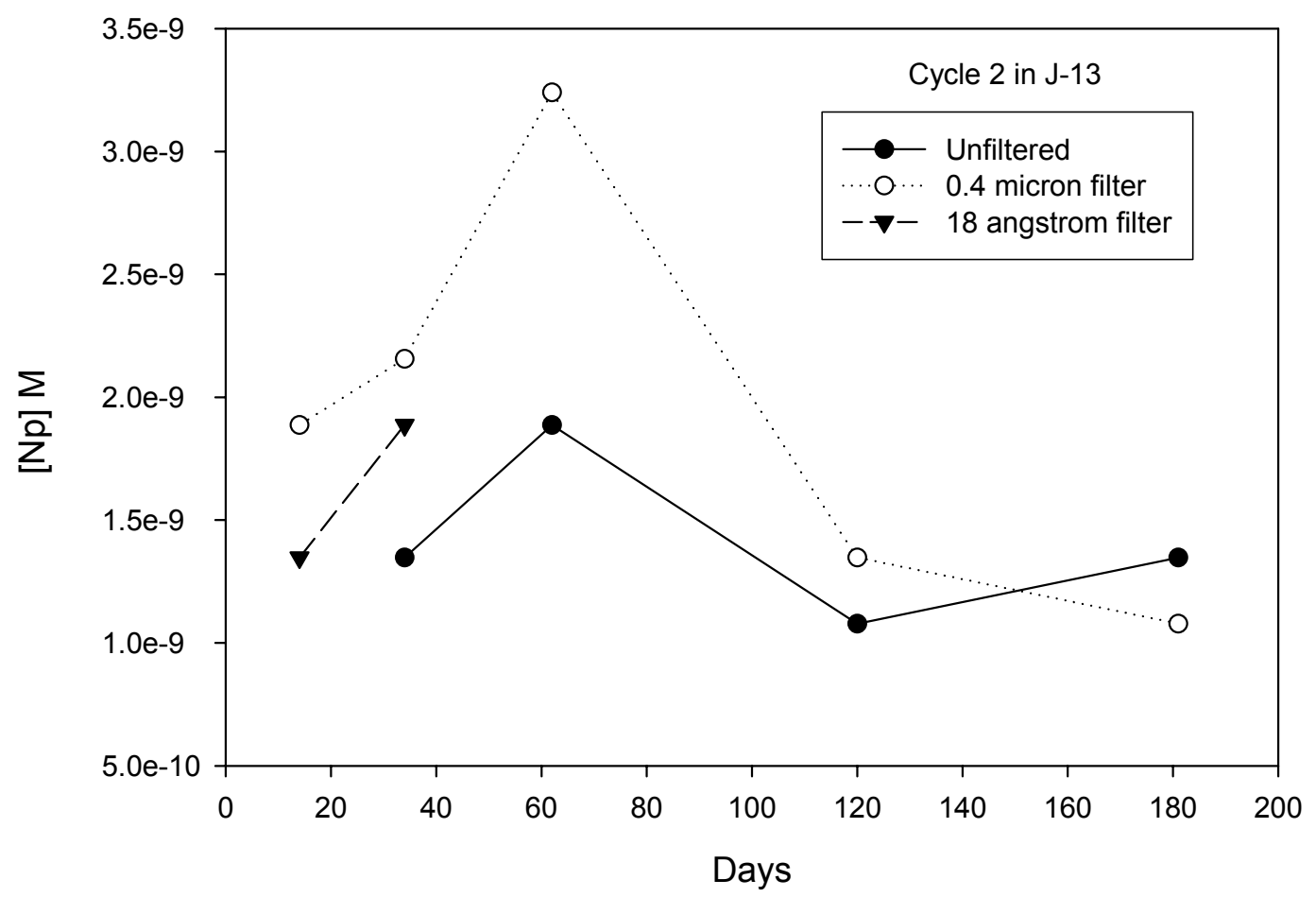

Figure 2.7. Neptunium Concentrations in Series 3 Cycle 2 Tests, Bare HBR Fuel at $25^{\circ} \mathrm{C}$ 


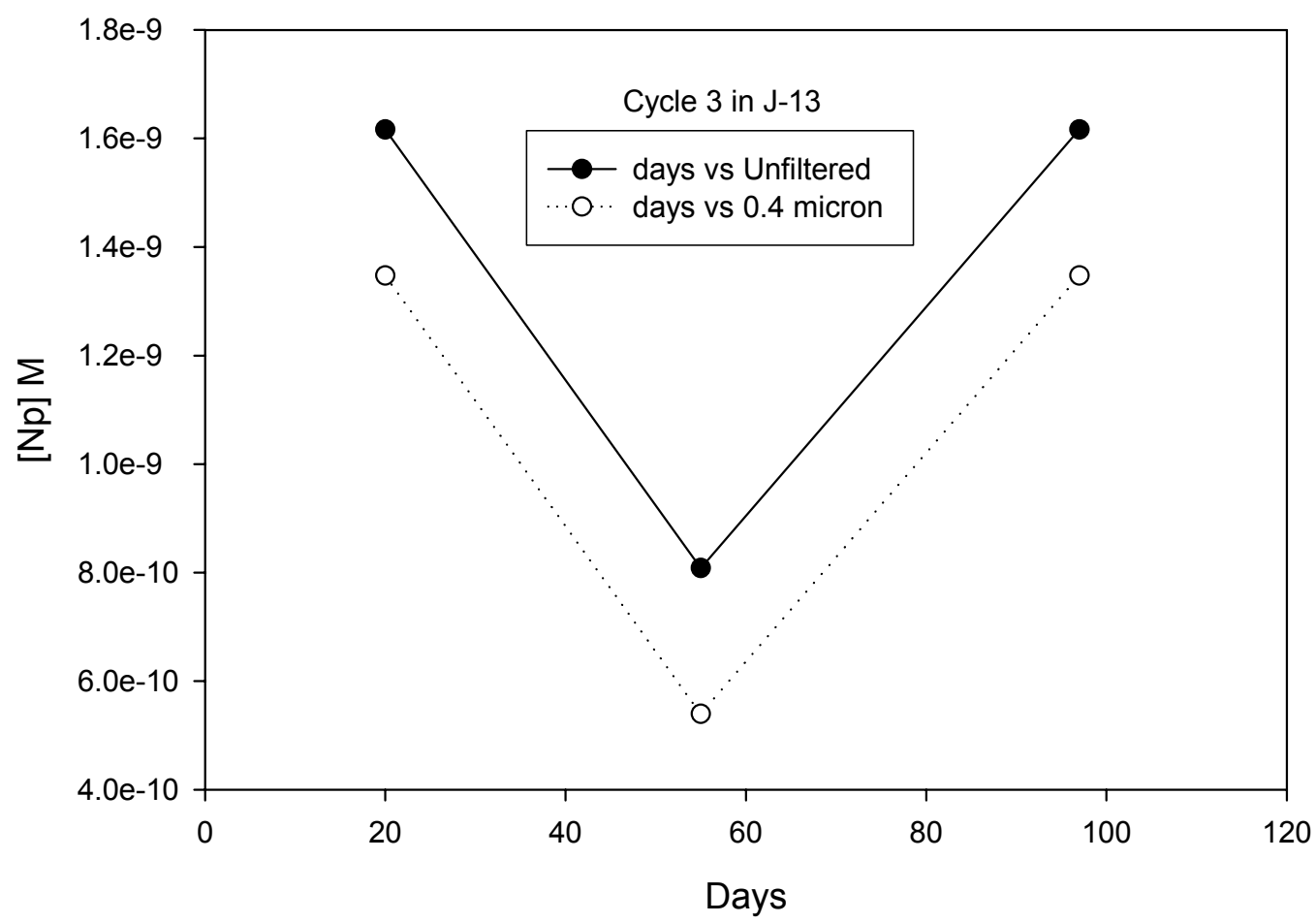

Figure 2.8. Neptunium Concentrations in Series 3 Cycle 3 Tests, Bare HBR Fuel at $25^{\circ} \mathrm{C}$

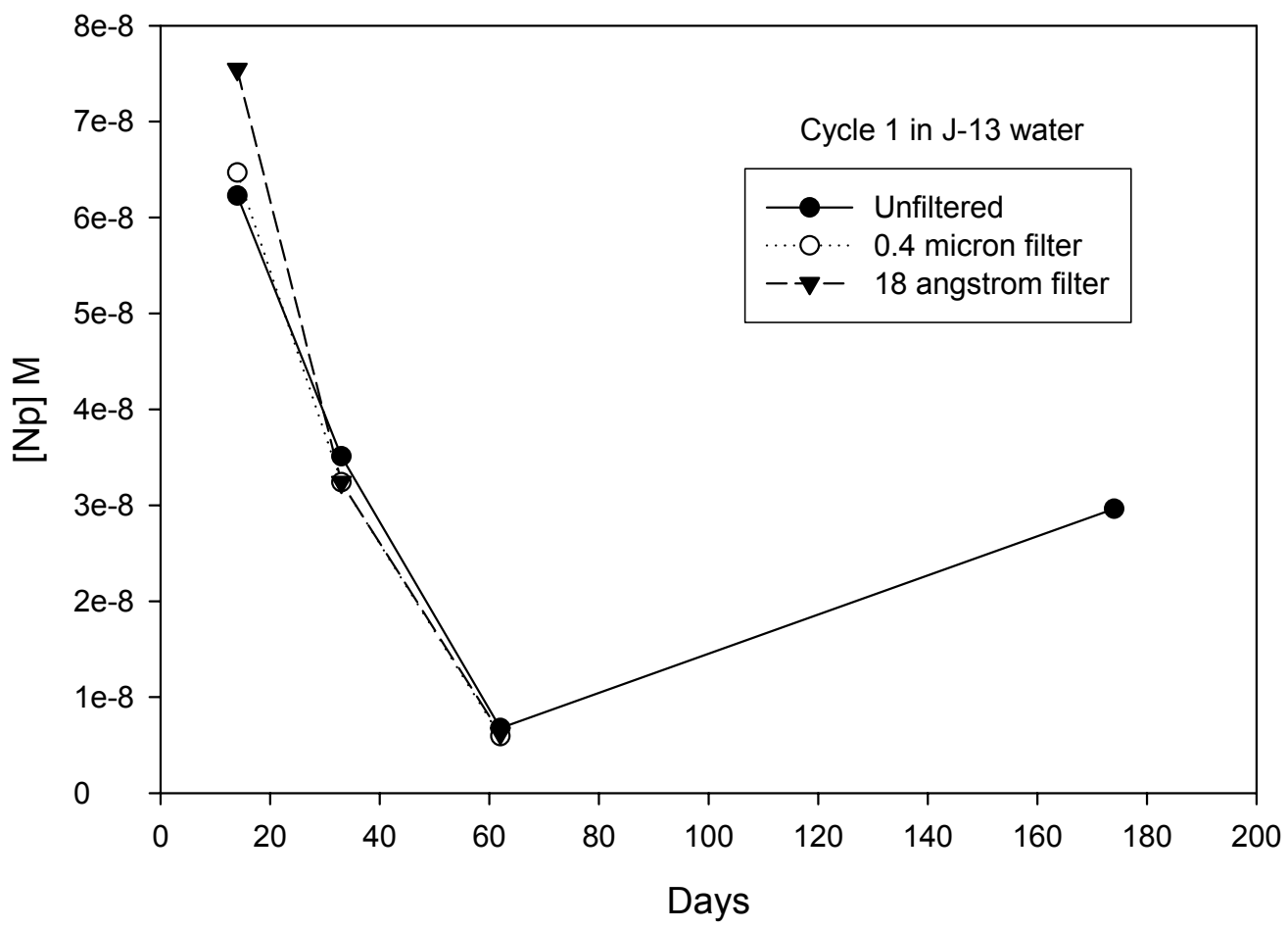

Figure 2.9. Neptunium Concentrations in Series 3 Cycle 1 Tests; Bare HBR Fuel at $85^{\circ} \mathrm{C}$ 


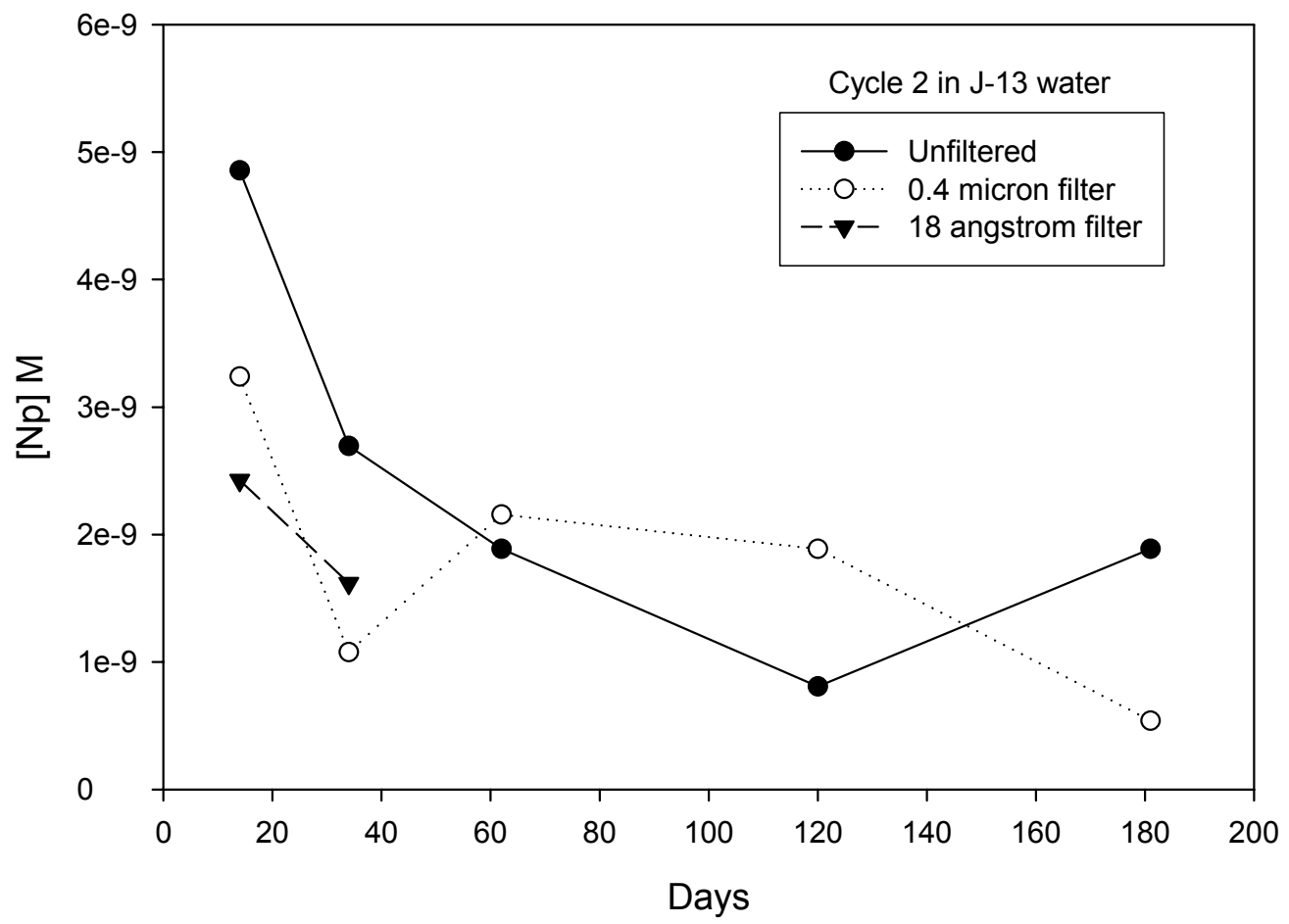

Figure 2.10. Neptunium Concentrations in Series 3 Cycle 2 Tests, Bare HBR Fuel at $85^{\circ} \mathrm{C}$

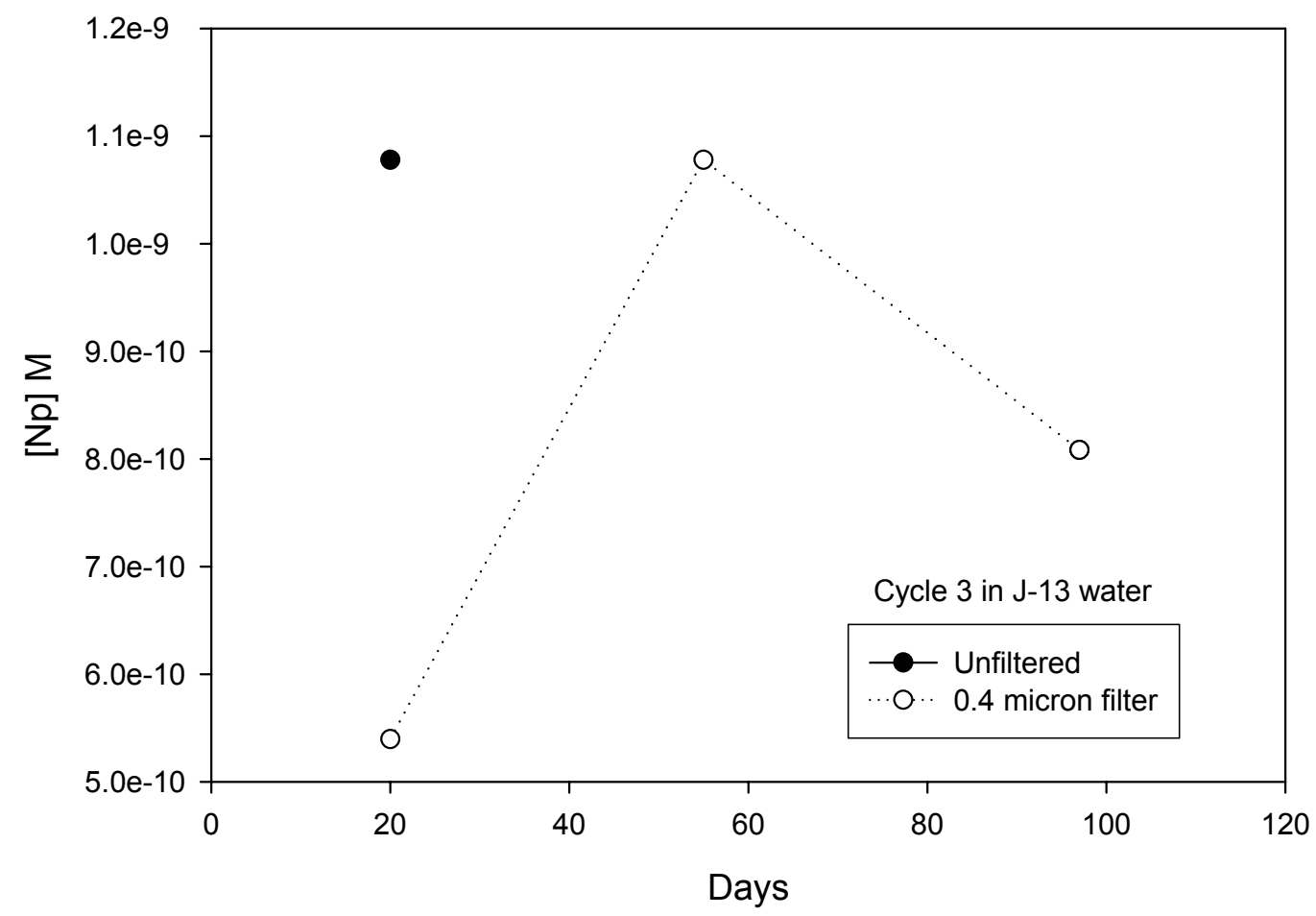

Figure 2.11. Neptunium Concentrations in Series 3 Cycle 3 Tests, Bare HBR Fuel at $85^{\circ} \mathrm{C}$ 


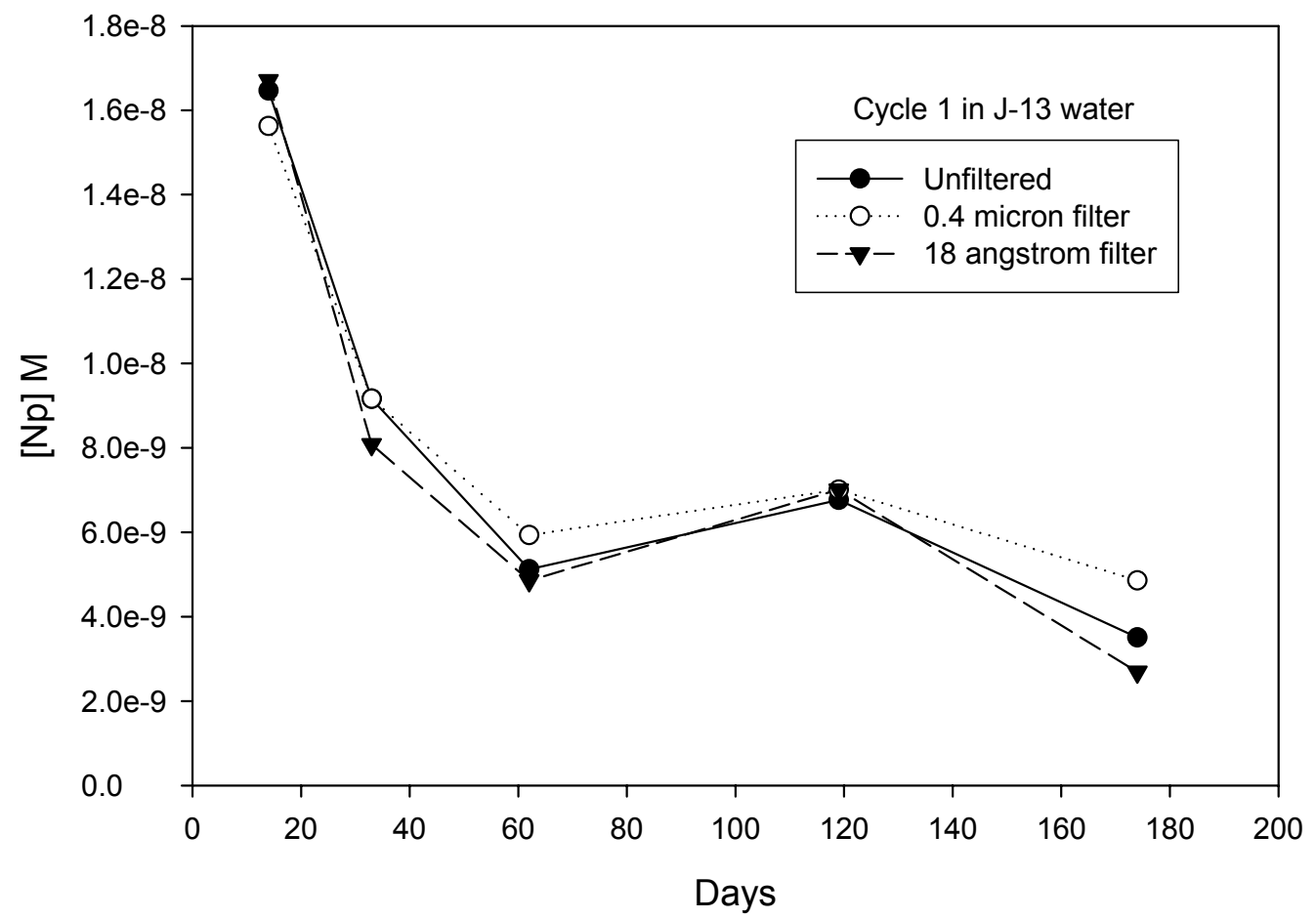

Figure 2.12. Neptunium Concentrations in Series 3 Cycle 1 Tests; Bare TP Fuel at $85^{\circ} \mathrm{C}$

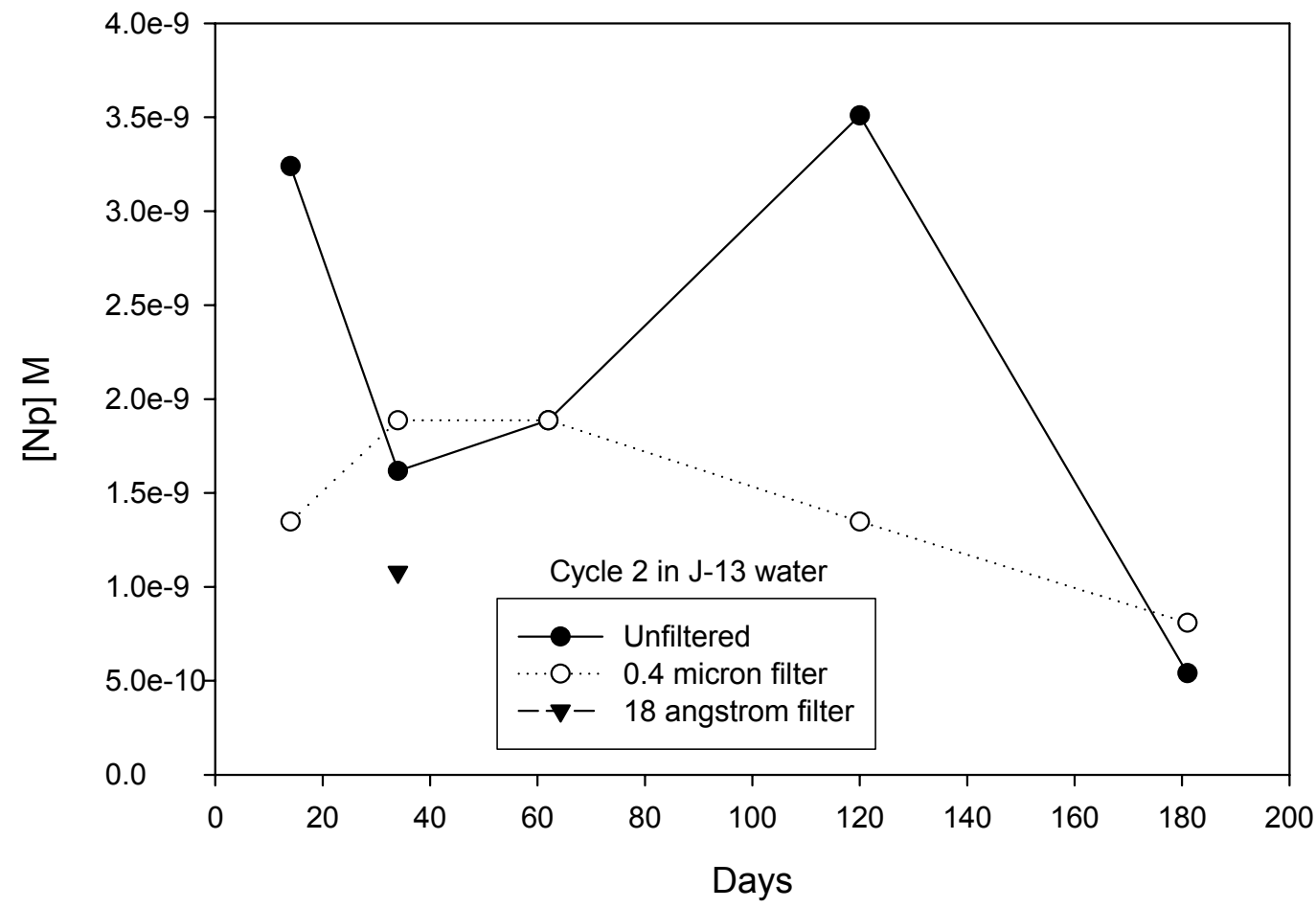

Figure 2.13. Neptunium Concentrations in Series 3 Cycle 2 Tests, Bare TP Fuel at $85^{\circ} \mathrm{C}$ 


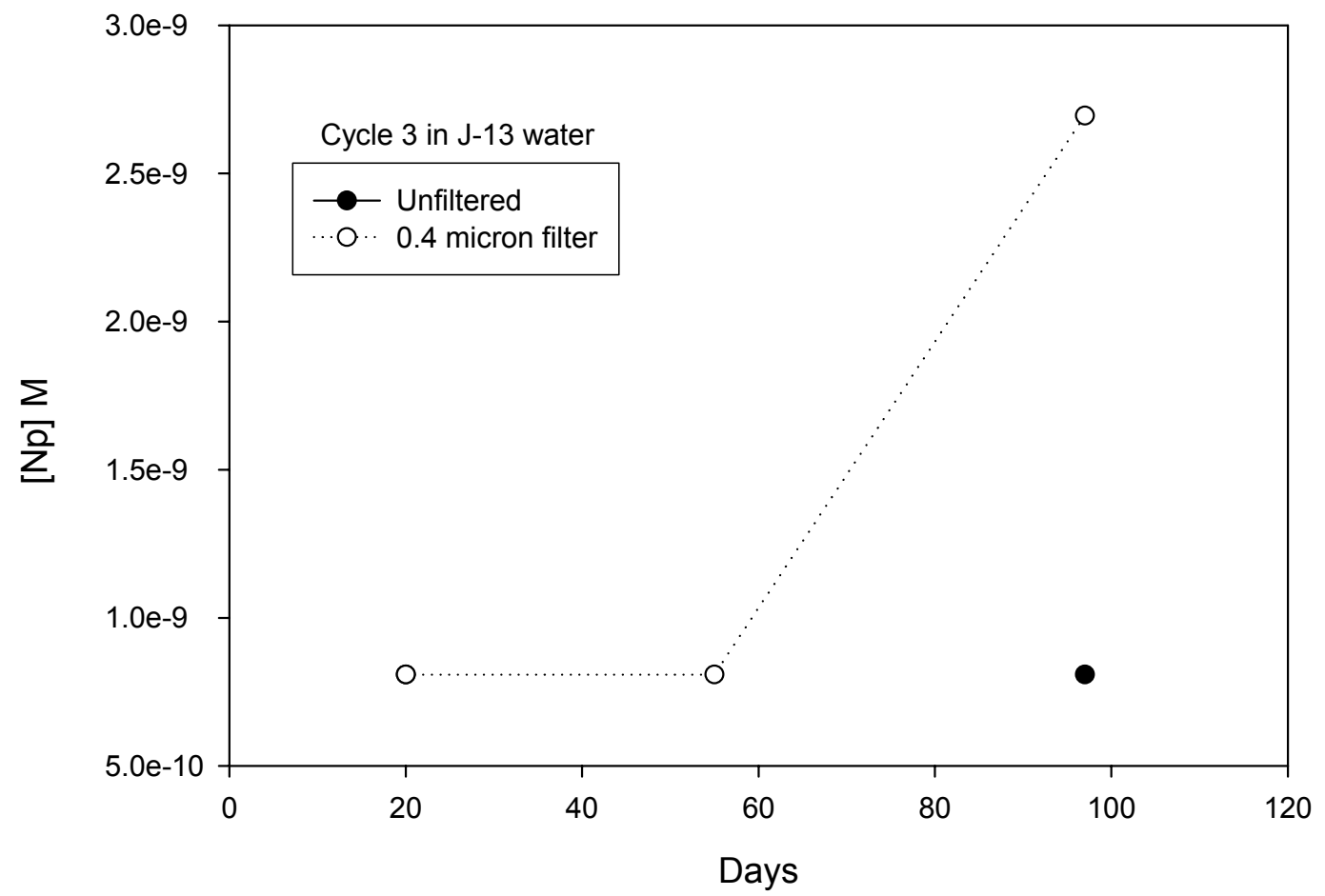

Figure 2.14. Neptunium Concentrations in Series 3 Cycle 3 Tests, Bare TP Fuel at $85^{\circ} \mathrm{C}$

Suspended particles in the test setup were filtered and analyzed by SEM and XRD. In Series 3, there were several uranium solid phases identified in these filtrates. In every case, various uranium silicates were observed, with uranophane being a predominant phase. Other phases, such as haiweeite and soddyite, were also observed. Unfortunately, a quantitative analysis of these phases was not performed at various times, so a correlation between a decrease in neptunium concentration and an increase in uranium silicate phases cannot be verified. However, there may be sorption and/or incorporation of neptunium into these phases as suggested by Burns et al. (1997).

There are several possibilities for the low neptunium concentrations in the Series 1, 2, and 3 tests. The solubility experiments by Efurd et al. (1998) establish a baseline concentration expected for neptunium in $\mathrm{J}-13$ water. They observed a neptunium concentration of approximately $10^{-5} \mathrm{M}$ that was controlled by the $\mathrm{Np}_{2} \mathrm{O}_{5}$ solid phase. The neptunium concentrations observed in the Series 1, 2, and 3 tests are four to five orders of magnitude lower than the $\mathrm{Np}_{2} \mathrm{O}_{5}$ controlled neptunium solubility. There are a number of potential reasons for this, including:

1. Not enough neptunium is corroded from the $\mathrm{UO}_{2}$ solid solution to increase the neptunium concentrations above the observed levels (release rates from fuel are slow).

2. There is a pure neptunium solid phase, such as $\mathrm{NpO}_{2}$ controlling the solution concentration.

3. The neptunium solution concentration is controlled by sorption/incorporation into uranium secondary phases or other material.

Each of the three possible mechanisms has both evidence for and against it based on the neptunium behavior in the Series 1, 2, and 3 tests. In each test series, the total uranium released was always at or 
below $10^{-5}$ of the total inventory of uranium in the tests. In the Series 3 bare fuel tests, $\approx 80 \mathrm{~g}$ of fuel was loaded. Neptunium accounts for 0.0309 percent of this by weight, which is $\approx 4.5 \times 10^{-5}$ mols of neptunium in each test. The congruent release of uranium and neptunium should release $\approx 1.05 \times 10^{-9}$ mols into solution. If all of this were in the $250 \mathrm{~mL}$ of solution in the tests, the concentration would be about $4.2 \times 10^{-9} \mathrm{M}$, which is about the concentration of neptunium measured in each of the solutions. Whereas this explains a potential reason for low neptunium concentrations, it does not explain why neptunium concentrations decrease rather than increase over time. If the concentration of neptunium were solely controlled by how much neptunium is released from the $\mathrm{UO}_{2}$ matrix, the concentration may be expected to increase with time, as long as additional matrix continues to react.

The formation of neptunium dioxide as the solubility-controlling phase is another possibility for explaining the low neptunium concentrations. The approximate concentration of neptunium in carbonate solution controlled by $\mathrm{NpO}_{2}$ would be about $5.0 \times 10^{-9} \mathrm{M}$ (Rai and Ryan 1985). This is close to the concentration range observed in the Series 1,2, and 3 tests, although it is important to note that all Series 3 tests eventually reached neptunium concentrations below this limit. The trend in lower neptunium concentration with time cannot be explained if $\mathrm{NpO}_{2}$ is formed at early times as might be suggested by the immediate drop in neptunium concentration. The formation of additional $\mathrm{NpO}_{2} \mathrm{would}$ not lower the solution concentration as observed in the experiments. This means that if a pure neptunium phase is controlling the solubility, then there are kinetic factors that determine when it forms. However, this seems unlikely because the neptunium concentration drops off rapidly initially and then continues to decrease.

The incorporation of neptunium into uranium corrosion products is also another potential mechanism to explain the behavior of neptunium. The trend of lowering the neptunium solution concentration with time correlates with the increase of uranium secondary phases. The identification of uranophane in the Series 3 tests indicates that potentially, neptunium incorporated into this phase may control neptunium solution concentrations. A potential problem with this reasoning is that neptunium displays similar behavior in DIW and J-13 water. Uranophane was present on the fuel in the presence of calcium and silica from the J-13 water; however, calcium is not present in the DIW experiments, thus preventing this formation of uranophane. There is a possibility of other uranium secondary phases incorporating neptunium, such as dehydrated schoepite. For this to be the case, dehydrated schoepite and uranophane must have about the same neptunium incorporation/sorption properties. This has never been determined experimentally.

The possibility of sorption may also be another mechanism for controlling neptunium solution concentrations. Sorption onto uranium secondary phases may explain the decrease in neptunium with time because an increase in the amount of secondary phase (and thus surface area) may take neptunium out of solution. It is a possibility that uranophane (from the J-13 water) and schoepite (from the DIW) may generate similar surfaces on which neptunium sorbs, giving the same neptunium behavior in different systems. The sorption of neptunium onto other materials present in the system (cladding and glass rods) should not give the decrease in neptunium concentration because the surface area of these materials should not change significantly with time unless the sorption is a relatively slow process compared to the initial release from the matrix.

The fate of neptunium cannot be unambiguously determined directly from the Series 1, 2, and 3 tests because of multiple possible explanations for the behavior of neptunium in the tests. The sample vessels 
were sealed from the atmosphere between sampling times. Thus, the only oxygen readily available for the oxidative dissolution of the fuel is the dissolved oxygen in the water, neglecting oxidants formed because of radiolysis. At $25^{\circ} \mathrm{C}$ and atmospheric pressure, this equals $8.2 \mathrm{mg}$ of $\mathrm{O}_{2}$ for every $1000 \mathrm{~mL}$. Each test began with only $250 \mathrm{~mL}$ of water, for a total of about $6.4 \times 10^{-5}$ moles of dissolved $\mathrm{O}_{2}$. After each sampling, the water was replenished for a total between $40 \mathrm{~mL}$ and $150 \mathrm{~mL}$ replaced during each cycle. Thus, the maximum dissolved oxygen available during any cycle was about $1.0 \times 10^{-4}$ moles, enough to react only $2.1 \times 10^{-4}$ moles $(\sim 0.06 \mathrm{~g})$ of $\mathrm{UO}_{2}$ to form $\mathrm{UO}_{3}$ (or $\mathrm{UO}_{2}{ }^{2+}$, which is equivalent). Considering that each test contained at least $27 \mathrm{~g}$ of fuel and was usually around $80 \mathrm{~g}$, there is only enough dissolved oxygen to react at most 0.2 percent of the fuel during any one cycle, assuming that there is no transport barrier to oxygen diffusion in water. While it is true that the headspace of air above the water can supply additional oxygen, this oxygen must first diffuse into the water and then transport down through the approximately 5 in. of water to the bare fuel at the bottom of the vessel. It is clear that the amount of oxygen available for reaction with the fuel is vastly sub-stoichiometric for the complete oxidation of uranium. Thus, unless the rate of the fuel oxidation/dissolution is much less than the diffusion of oxygen through water, it is clear that the reaction will be limited because of the oxygen deficiency. The fact that the systems have limited oxygen, and thus a lower oxygen potential, may influence the behavior of neptunium in these tests. This difference in behavior may cause the neptunium oxidation mechanisms in the tests to be different than would be the case in Yucca Mountain. The rate of reaction and the incorporation of neptunium may not be the same as will occur with the chemical potential governed by the assumed constant 20 percent $\mathrm{O}_{2}$ overpressure at Yucca Mountain.

A comparison of the Series 3 data with predications using the EQ3/6 geochemical modeling program was done to determine whether steady-state actinide concentrations measured in the laboratory dissolution tests could be related to the precipitation of actinide-bearing solids (Wilson and Bruton 1989). $\mathrm{NpO}_{2}$ was modeled as the controlling phase. The Series 3 report says the neptunium concentration was highly dependent on Eh and $\mathrm{pH}$. However, to obtain agreement between the predictions and measured values of neptunium, the oxygen fugacity had to be set to $10^{-12}$ rather than atmospheric levels. This is further evidence that the Series 1,2 , and 3 tests are oxygen deficient, which, according to the model, dramatically affects the dissolved neptunium concentrations by several orders of magnitude.

The Series 1, 2, and 3 tests were not set up to understand neptunium behavior, but they do yield some insight into potential mechanisms controlling neptunium-dissolved concentrations. One of these mechanisms, a combination of them, or some other currently unidentified mechanism may control the neptunium concentration. Further experimental evidence is needed to understand the fate of neptunium under repository relevant conditions.

\subsection{Unsaturated Flow Tests (Drip Tests)}

A number of tests carried out at Argonne National Laboratory (ANL) seek to understand the leaching behavior of commercial spent nuclear fuel (CSNF) under low-flow-rate conditions. A description of the experimental setup can be found from CRWMS M\&O (2000).

The neptunium data from three of the drip tests are shown in Figures 2.15 through 2.17. In general, both fuels used (ATM-103 and ATM-106) showed similar trends in neptunium concentration. The ATM-106 data in the ANL low-drip-rate tests at 3.1 years show a substantial increase in the neptunium concentration. This is caused by a brief immersion of the fuel in the collected leachate. 


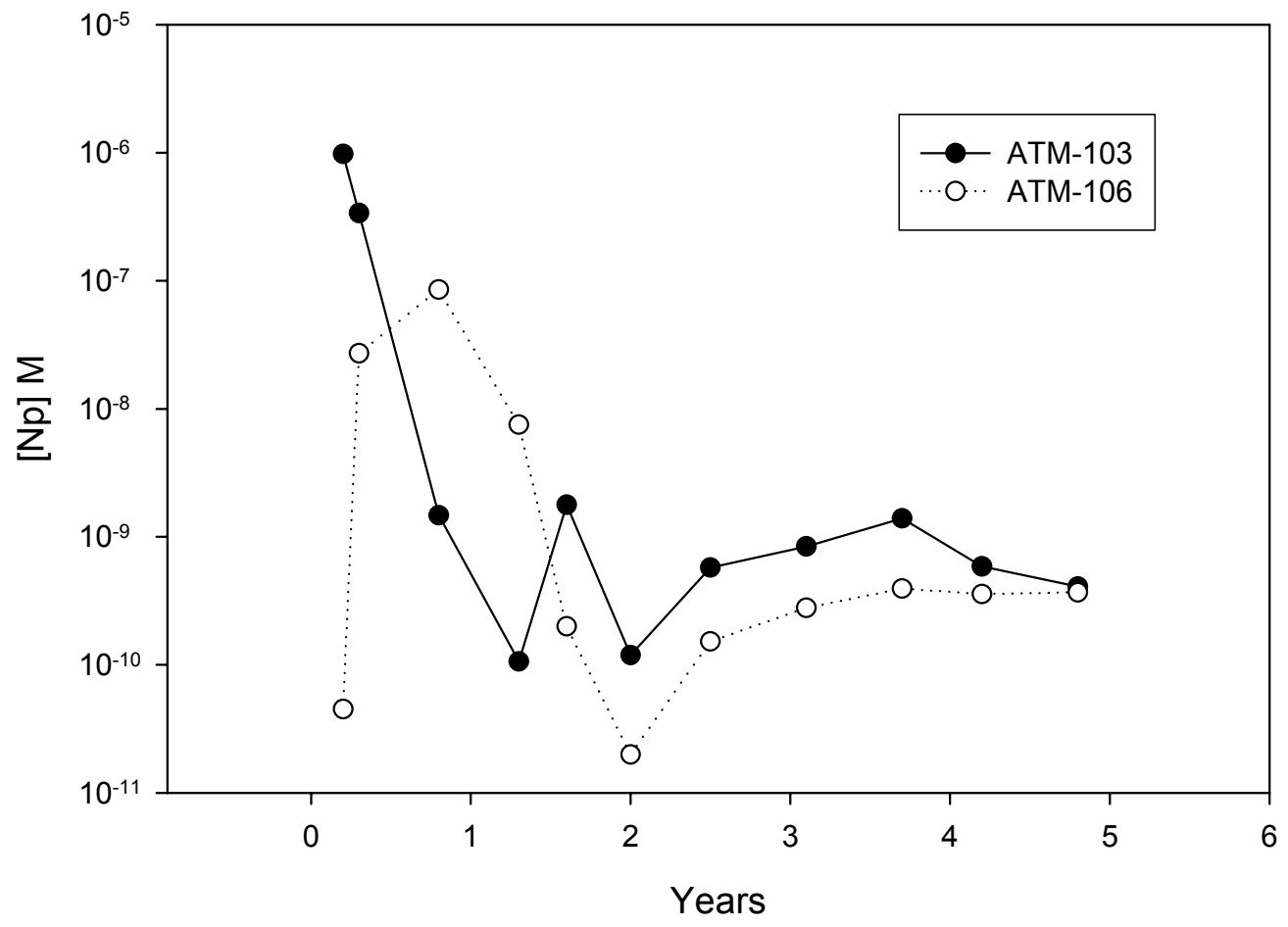

Figure 2.15. Neptunium Concentrations in ANL High Drip Rate Tests



Figure 2.16. Neptunium Concentrations in ANL Low Drip Rate Tests 


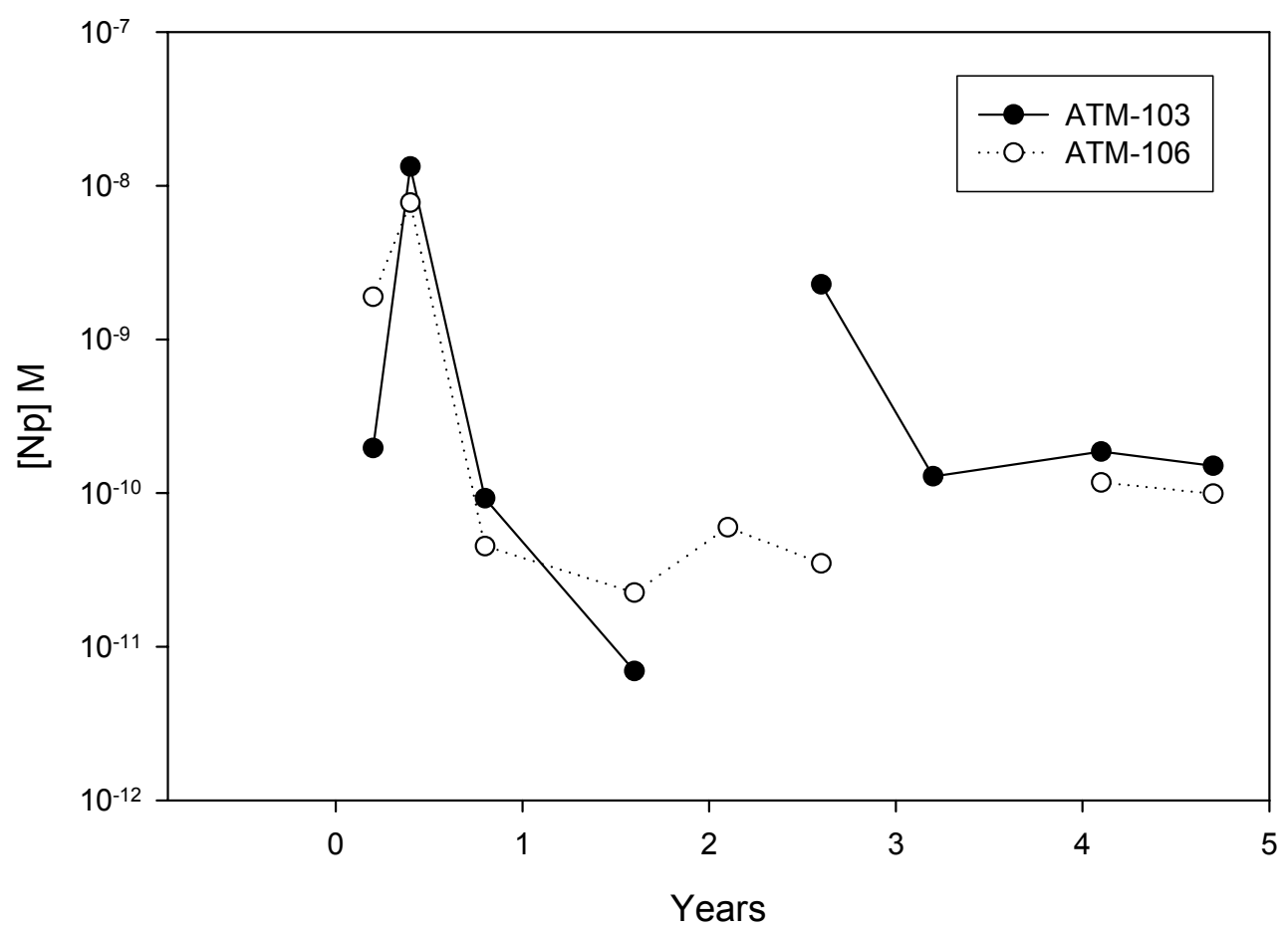

Figure 2.17. Neptunium Concentrations in ANL Vapor Tests

It is interesting to note that the general trends in neptunium concentrations are quite similar to the Series 1,2 , and 3 tests. There is a general decrease in neptunium concentration with time. The lower concentrations in the drip tests are about the same as the Series 1,2, and 3 tests. The time scale in the decrease in neptunium concentrations is slower in the drip tests. The same trends on different time scales may be caused by the difference between immersion tests (Series 1, 2, and 3 data) and dripping water. However, in the drip tests, the residence time and flow path of the dripping water is unknown, which may cause parts of the fuel to be subjected to different conditions. Fuel that is in direct contact with the dripping water may have different chemical behavior than fuel that does not contact dripping water but only moist air. The sampling that is done about every 6 months will be an average of several different reactions occurring over several months. This limits mechanistic information needed to predict neptunium behavior.

The interpretation of these tests ${ }^{(a)}$ suggests that the retention of neptunium in the drip experiments with Sisaturated water may be caused by one or more of several factors, including:

1. Incomplete oxidation of the $\mathrm{Np}(\mathrm{IV})$ in the fuel to $\mathrm{Np}(\mathrm{V})$ under experimental conditions

2. Coprecipitation of neptunium in $\mathrm{U}(\mathrm{VI})$ compounds

3. Sorption of $\mathrm{Np}$ into existing solids, test vessel components, or both

4. Ion exchange of neptunium species with cations in existing minerals.

These suggested mechanisms are similar to suggested mechanism for the Series 1, 2, and 3 tests.

(a) RJ Finch and JA Fortner, Progress report. 
The first mechanism (incomplete oxidation) may indicate the formation of an $\mathrm{NpO}_{2}$ neptunium phase. Similar to the Series 1,2, and 3 tests, the drip tests are oxygen deficient in that there is only enough oxygen present during any cycle to react at most 1 percent of the fuel, and the formation of tetravalent neptunium solids remains a possibility that needs to be tested experimentally under repository conditions. However, from Figures 2.15 through 2.17, it is clear that in all three drip scenarios, the neptunium concentration is often below the concentrations expected if $\mathrm{NpO}_{2}$ were the controlling phase. The second mechanism for neptunium holdup (coprecipitation with uranium) remains a possibility and explains the decrease in neptunium concentration with time because of the increase in U(VI) secondary phases over time. The phases that form in the vapor tests will be different than the other two drip tests because the water in contact with the fuel will have a different chemistry. For example, the uranyl silicate phases that form in the drip tests cannot form in the vapor tests where only schoepite has been observed. Because the neptunium concentrations in all three scenarios are so similar, the coprecipitation mechanism would only be valid if dehydrated schoepite has a similar capability to incorporate neptunium as the U(VI) silicates. Experimental evidence for this is needed to validate this possibility. The third mechanism (sorption) suggested can explain neptunium holdup; however, it does not explain the decrease in neptunium concentrations with time unless the sorption involves the in-growth of surface area with time. The fourth mechanism (ion exchange) is similar to the second where the neptunium is associated with the U(VI) phases. The authors correctly indicate that this mechanism may be minimal because of the high concentration of other cations in solution and the low concentration of neptunium.

The neptunium behavior in the drip tests was not exactly similar to that of the Series 1, 2, and 3 tests. Figures 2.18 through 2.20 show the $[\mathrm{Np}] /[\mathrm{U}]$ ratios for the Series 3, the ANL high drip, and ANL low drip tests, respectively. It appears that there is more neptunium in solution relative to uranium than in the original fuel. This indicates that the presence of excess water may cause neptunium to be mobilized. This also indicates that the most likely oxidation state for neptunium is +5 because it is unlikely that tetravalent neptunium would be in solution in a neptunium/uranium ratio different than in the fuel. A second interesting observation is the change in the $\mathrm{Np} / \mathrm{U}$ ratio with time in the drip tests. The cumulative release (Figures 2.21 and 2.22) of uranium and neptunium show virtually no change with both elements after about 1 to 1.5 years. The changing $N p \backslash U$ ratio without a dramatic release of either element may indicate that corrosion of the fuel has dramatically slowed with time. 


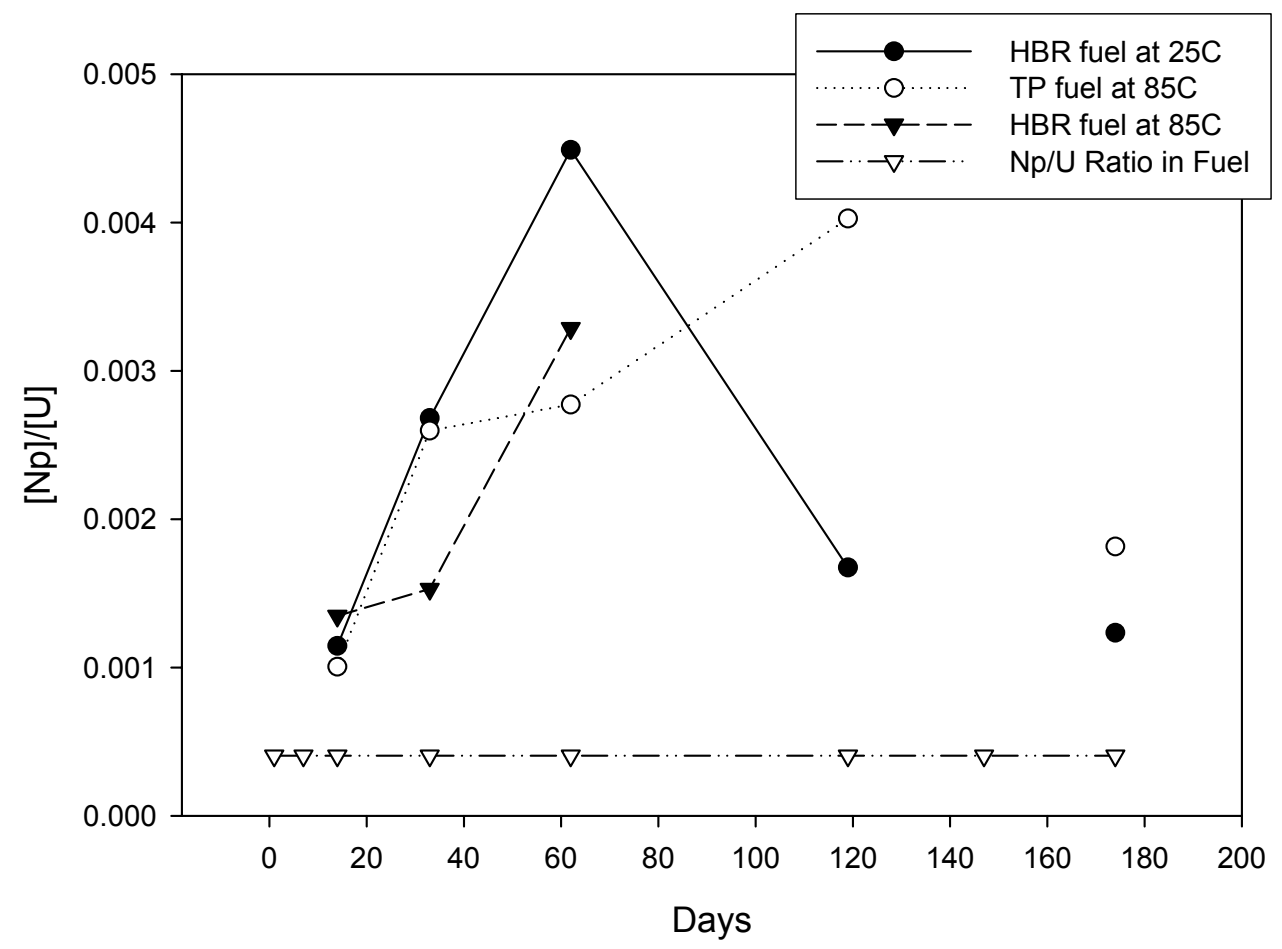

Figure 2.18. $[\mathrm{Np}] /[\mathrm{U}]$ Ratio from Series 3 Tests

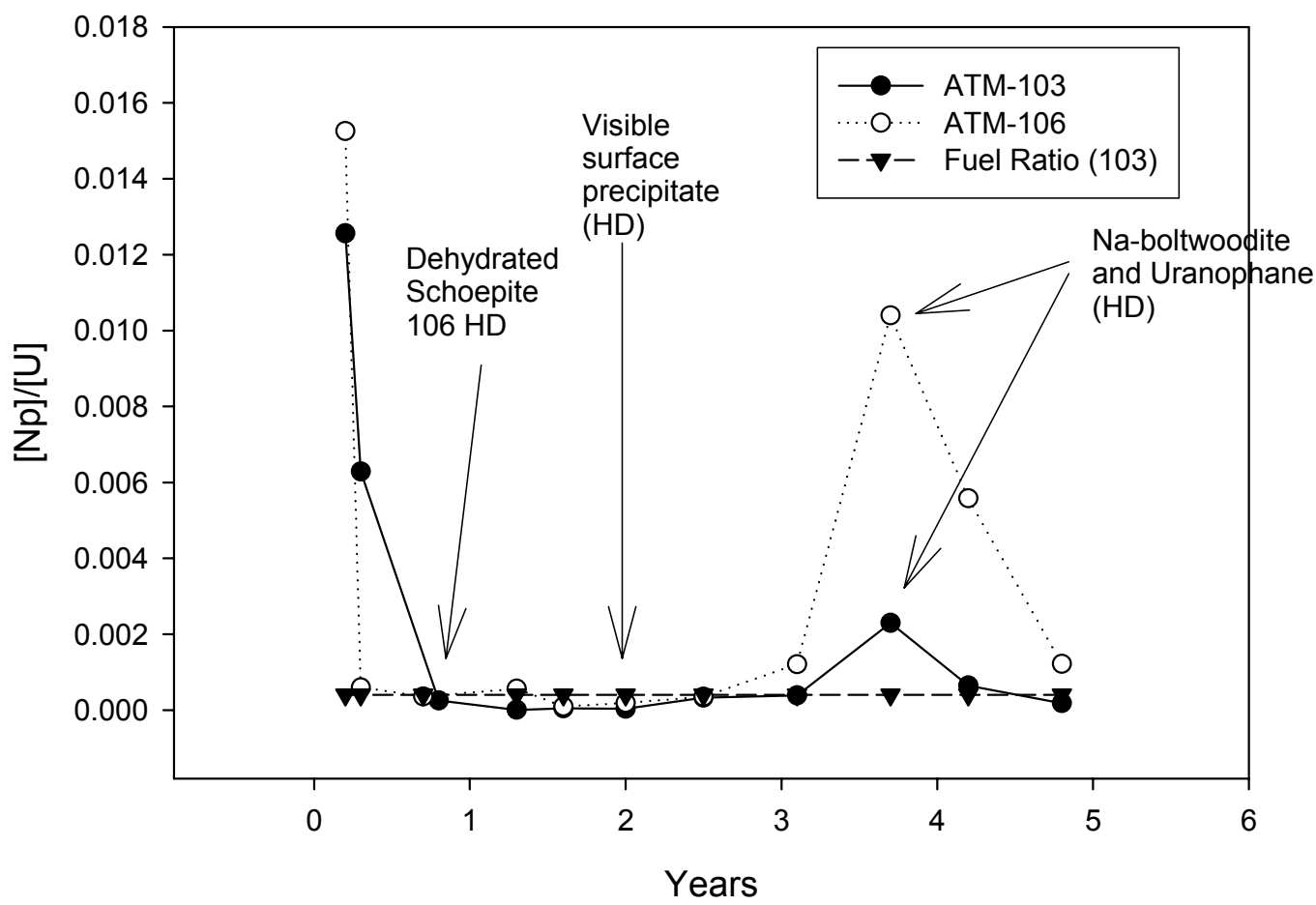

Figure 2.19. $[\mathrm{Np}] /[\mathrm{U}]$ Ratio from ANL High Drip Rate Tests 


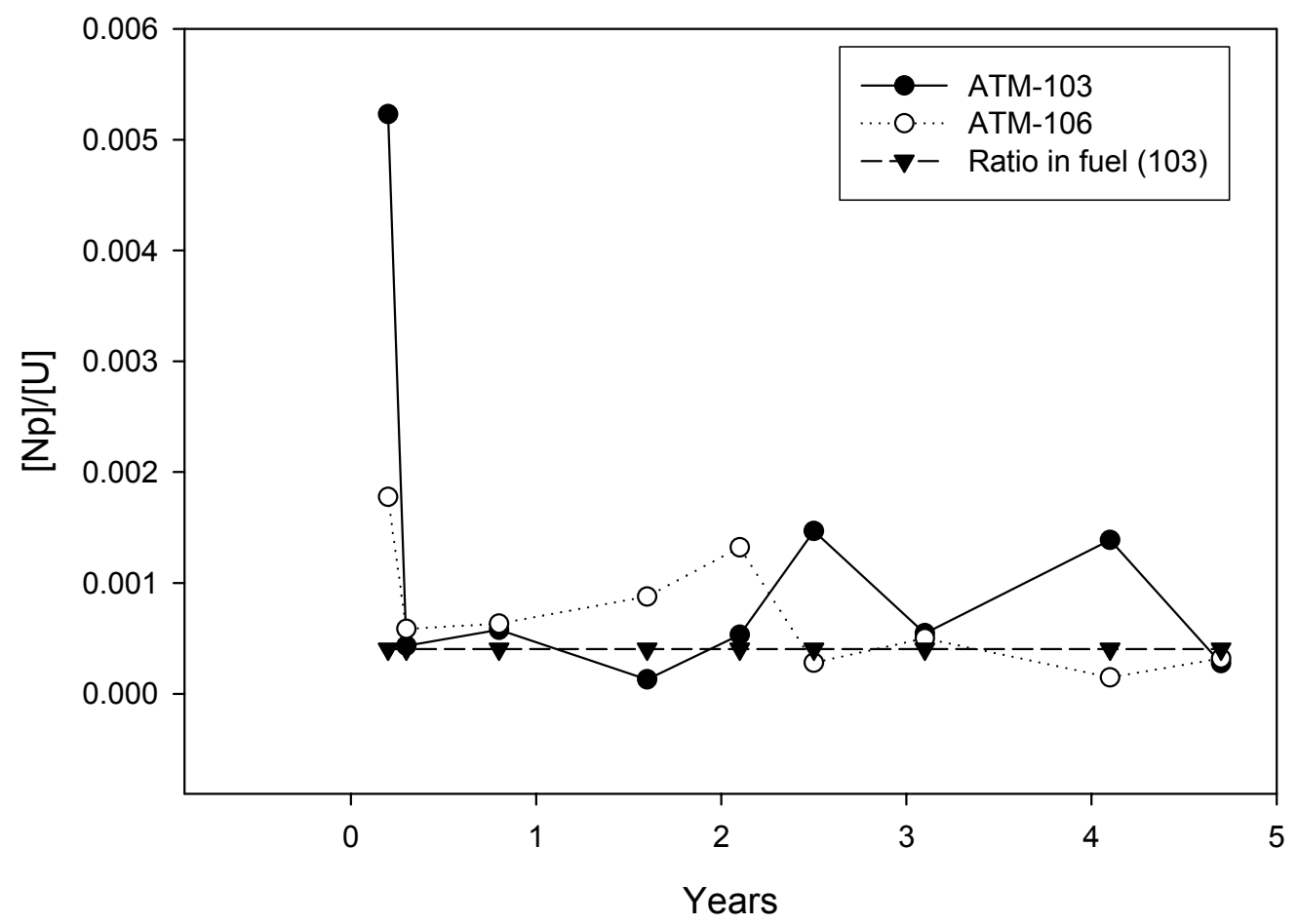

Figure 2.20. [Np]/[U] Ratio from ANL Low Drip Rate Tests

High Drip Rate

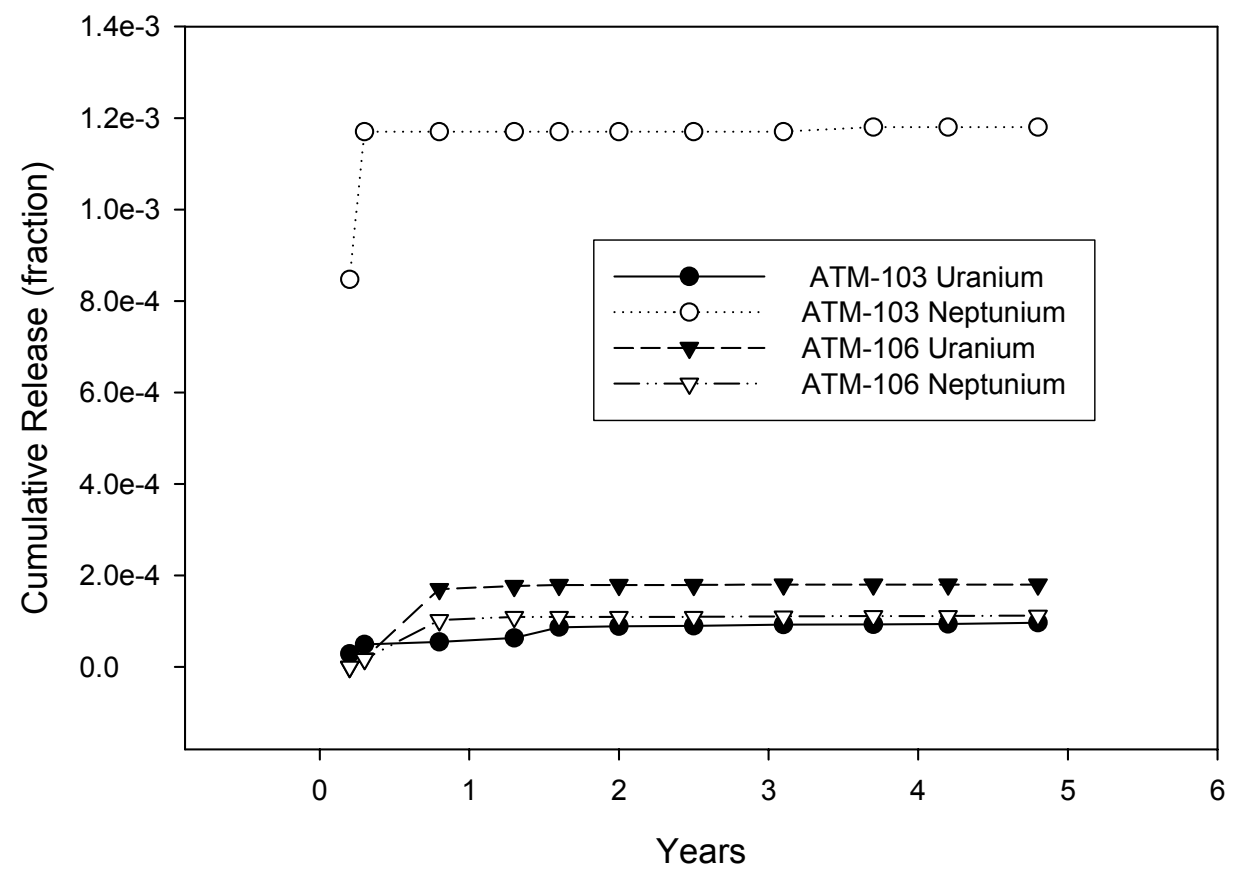

Figure 2.21. Cumulative Release of Neptunium and Uranium from High Drip Rate Tests 


\section{Low Drip Rate}

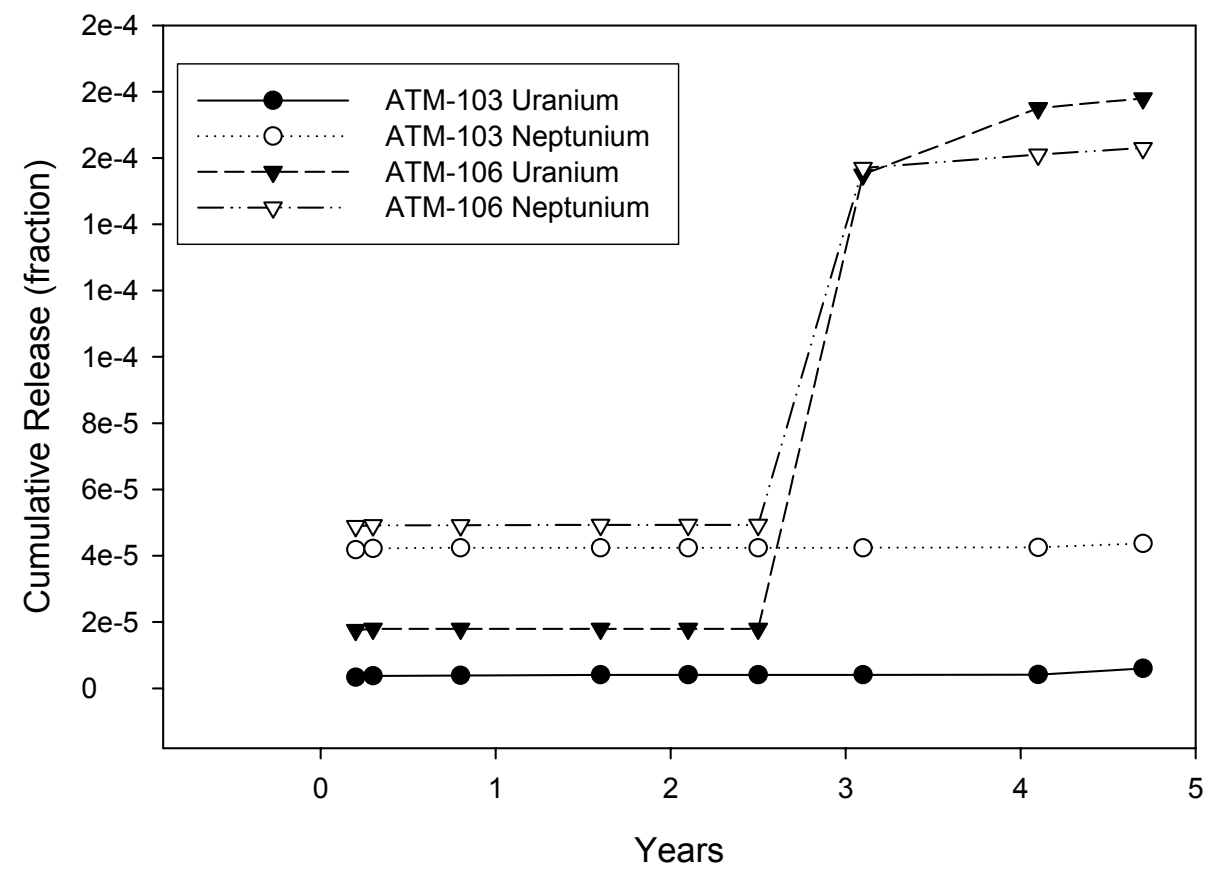

Figure 2.22. Cumulative Release of Neptunium and Uranium from Low Drip Rate Tests

The higher $\mathrm{Np} / \mathrm{U}$ ratio in solution compared to original fuel indicates that the neptunium release to the environment may be different than that of uranium. Regardless of the phase or phases controlling neptunium concentrations, the preferential environmental release of neptunium in both the Series 1,2, and 3 tests and the drip tests indicates the importance of understanding neptunium's chemistry under repository conditions. The variation in the $\mathrm{Np} / \mathrm{U}$ ratio in both cases may indicate that new phases are forming. However, there is a lack of information as to which phases are forming and the effect of the phases on neptunium concentration. It is unlikely that the conversion from one uranium phase to another can explain the change in the ratio in the drip tests because one would expect a gradual shift between phases. This continuous shift would gradually lower neptunium concentrations (if neptunium is incorporated) rather than cause an increase and a decrease in the ratio.

\subsection{Progress Report on Dissolved Concentration Limits: Neptunium in Alteration Phases}

Because the results were ambiguous in determining the fate of neptunium in the Series 1,2, and 3 and drip tests, ANL designed experiments to test neptunium's interaction with U(VI) alteration phases and presented them in a preliminary progress report. ${ }^{(a)}$ Four $\mathrm{U}_{3} \mathrm{O}_{8}$ neptunium solids were synthesized at various molar ratios, 1:8, 1:26, 1:80, and 1:160. All of these ratios are much higher than the expected ratios in SNF, which eliminates various analytical detection difficulties with neptunium, but the first three are so high that the chemistry of the system may have been affected. These doped solids were placed in a sealed container with water-saturated air and heated at various temperatures. The solids were

(a) RJ Finch and JA Fortner, Progress report. 
characterized by SEM, energy electron-loss spectroscopy (EELS), XRD, energy dispersive spectroscopy (EDS), extended X-ray absorption fine structure (EXAFS), and X-ray absorption near edge structure (XANES). Neptunium was determined to be $\mathrm{Np}(\mathrm{IV})$ in the starting material by EXAFS. However, it is unclear how neptunium in the 4+ state could substitute for uranium that is either $5+$ or $6+$ without some charge compensation, such as loss of oxygen. Only observations from the 1:8 and 1:80 samples are presented in the report.

The 1:8 ratio sample indicated no visual evidence of corrosion after 2 weeks at $90^{\circ} \mathrm{C}$. After an additional 10 days at $150^{\circ} \mathrm{C}$, yellow crystals were visible using an optical microscope. Dehydrated schoepite was identified by SEM. The XRD pattern indicated the presence of the starting material $\left(\mathrm{U}_{3} \mathrm{O}_{8}\right)$, dehydrated schoepite, and a diffraction pattern that closely matches $\mathrm{NpO}_{2}$ (or $\mathrm{UO}_{2}$ ). The mechanism as to how the $\mathrm{Np}$ could be reduced from solution to form $\mathrm{NpO}_{2}$ is not clear; however, this would require there to be $\mathrm{U}(\mathrm{IV})$ present in the system, and initial analysis shows that the starting material was $\mathrm{U}_{3} \mathrm{O}_{8}$. Also, this mechanism assumes that the $\mathrm{Np}$ (IV) in the starting material was oxidized to a higher state, released to solution, reduced back to (IV), and precipitated. Some substitution of neptunium occurs in the $\mathrm{U}_{3} \mathrm{O}_{8}$ matrix, as is evident from the lattice parameter contraction, but the $\mathrm{NpO}_{2}$ may have existed all along. A similar sample at $90^{\circ} \mathrm{C}$ after 16 weeks of reaction revealed a dark-gray powder with a small number of yellow crystals within. An XRD of the lower temperature solid indicated the presence of dehydrated schoepite and metaschoepite as major corrosion products. The authors also tentatively assigned several weak signals in the XRD pattern to $\mathrm{NpO}_{2}$ and $\mathrm{Np}_{2} \mathrm{O}_{5}$.

The 1:80 ratio sample showed abundant crystals of dehydrated schoepite after two weeks at $150^{\circ} \mathrm{C}$ by SEM. An XRD of this sample only indicated the presence of the starting material $\left(\mathrm{U}_{3} \mathrm{O}_{8}\right)$ and dehydrated schoepite. At $90^{\circ} \mathrm{C}$ and 16 -week reaction time, the sample had abundant yellow crystals on the surface of the sample. XRD reveals two uranium phases, dehydrated schoepite and metaschoepite. There was no evidence of $\mathrm{NpO}_{2}$ or $\mathrm{Np}_{2} \mathrm{O}_{5}$ for the 1:80 samples.

The preliminary progress report states that very little neptunium was associated with the uranium solid phases. It is estimated that less than $1 \mathrm{wt} \%$ can be within (or adsorbed onto) dehydrated schoepite. Another suggested possibility is that there is no neptunium in dehydrated schoepite. Due to the lack of experimental evidence for neptunium association with the uranium solid phases, the report suggests using $\mathrm{NpO}_{2}$ as the solubility-limiting phase as realistic and conservative for the Yucca mountain repository.

This set of experiments does not involve the fuel in contact with water, so solution concentration of neptunium cannot be compared with previous experiments. Because only one of the tests $(1: 8$ ratio at both $90^{\circ} \mathrm{C}$ and $150^{\circ} \mathrm{C}$ ) showed evidence for $\mathrm{NpO}_{2}$, it is premature to recommend using $\mathrm{NpO}_{2}$ as the solubility-limiting phase. Even if $\mathrm{NpO}_{2}$ does form by the reduction of pentavalent neptunium, the solubility would not solely be controlled by tetravalent neptunium, but rather a combination of neptunium(V) and neptunium(VI). A review of the current literature concludes that $\mathrm{NpO}_{2}$ has never been reported to form under conditions expected in the repository, even though it is predicted to be the stable phase based on thermodynamics. 
The following additional experiments related to these experiments are needed to determine if these observations are relevant to the repository:

1. Using constant oxygen concentration (atmospheric levels) rather than using a sealed vessel.

2. SNF will have other ions present that may offer a charge-balance mechanism for incorporating neptunium into dehydrated schoepite that is not present in these tests. Counter ions for charge balancing are necessary to incorporate neptunium into neutral sheet structures in uranium solid phases.

3. SNF will have a radiation field associated with it, and effects of this field need to be determined.

4. $\mathrm{SNF}$ is $\mathrm{UO}_{2}$, which has different physical and chemical properties than $\mathrm{U}_{3} \mathrm{O}_{8} . \mathrm{UO}_{2}$ experiments are necessary to confirm the use of $\mathrm{U}_{3} \mathrm{O}_{8}$ as an appropriate surrogate for SNF. Whereas thermodynamically, the end products of reactions are not affected by the starting material, the kinetic rate and how the reaction proceeds are dependent on starting material. $\mathrm{U}_{3} \mathrm{O}_{8}$ may be a good surrogate; however, this needs to be confirmed for use in the models.

A recent Environmental Management Science Program (EMSP) initial report by Burns et al. indicates that Np-doped U oxyhydroxides form a solid solution with $\mathrm{Np}$ up to about 20 percent mol ratio (Burns et al. 2001). This oxyhydroxide was identified as the uranyl peroxide studtite. Neptunium was also observed in studtite formed from SNF by McNamara et al. (2002). Both experiments (unirradiated uranium and SNF) identified neptunium in studtite. Studtite forms under highly oxidizing conditions, and neptunium is expected to be $\mathrm{Np}(\mathrm{VI})$. $\mathrm{Np}(\mathrm{VI})$ needs no charge-balancing mechanism for incorporation into uranium solids and seems to readily incorporate into studtite. Because $\mathrm{Np}(\mathrm{V})$ is isostructural with $\mathrm{U}(\mathrm{VI})$, but has a different charge, and the fact that $\mathrm{Np}(\mathrm{VI})$ readily substitutes for $\mathrm{U}(\mathrm{VI})$, may indicate that the presence of counter ions is important for neptunium substitution into uranium solid phases. 


\subsection{Discussion and Recommendations}

An overview of selected experimental evidence of neptunium behavior under a variety of conditions gives insight into the fate of neptunium in a repository. The nature of neptunium behavior is still not clear, and there are many possible mechanisms for holdup. Future experiments must be designed to test each mechanism to determine its importance under repository-relevant conditions. The previous experiments provide a basis for designing future tests to be performed under repository-relevant conditions.

Previous solubility experiments with DIW and J-13 water give an upper limit of potential neptunium solubility controlled by the pure neptunium solid-phase $\mathrm{Np}_{2} \mathrm{O}_{5}$. All experimental solutions containing neptunium were lower than this solubility over the entire $\mathrm{pH}$ range. This would seem to indicate that neptunium solubility is not defined by $\mathrm{Np}_{2} \mathrm{O}_{5}$, but some other mechanism. One must be careful with this type of statement because previous experiments were not under repository conditions, and they potentially underestimate neptunium concentrations. It is necessary to determine this with future tests under more controlled conditions.

The Series 1, 2, and 3 tests were "bathtub" type experiments with SNF. One potential limitation of the Series 1, 2, and 3 experiments is that they were not designed to probe neptunium behavior from SNF. The main goal of the experiments was to determine the different concentrations of radionuclides in solution with different types of breached cladding.

A second limitation of the Series 1,2, and 3 data is that conditions are different from expected repository conditions. In the Series 1 and 2 tests, there was an excess of silica. The glass rods were added to the setup, and the vessel itself is glass. This excess silica had two major effects on the results. All solids that were analyzed were coated with a silica gel. The effect of a large excess of silica in contact with fuel is unknown, but may readily affect the rate of corrosion. Excess silica can also affect the type of U(VI) solid phases that form. For example, Series 3 was in stainless steel vessels, and whereas the neptunium behavior was not markedly different, the release of other radionuclides (such as technetium) was affected by the lower silica concentration and the use of an iron-containing vessel. The interaction of neptunium with solutions with excess silica as seen in the drip tests and Series 1, 2, and 3 tests may give results different than what will happen in the repository.

A third limitation of the Series 1,2, and 3 experiments is that as a "bathtub" test, the oxygen available for oxidation is fairly limited to the dissolved oxygen in the water. Oxygen is expected to be the main electron acceptor in $\mathrm{UO}_{2}$ corrosion. Any change in oxygen content in an experimental setup (about $8.2 \mathrm{ppm}$ in water and 21 percent in air) may change the rate of oxidation of SNF. If neptunium behavior is kinetically controlled, rates different than what will be in the repository may misrepresent expected neptunium solubility.

The Series 1, 2, and 3 tests are a good start in understanding neptunium behavior. Similar experiments that meticulously control the solution chemistry and oxygen content would give important information on solubility. Other variables can easily be tested, such as the presence of iron and iron oxides to simulate waste packages that would provide potential reducing ions that could affect rates of reaction and what phases form. The U(VI) solid phase should be carefully characterized in all experiments. Ideally, these experiments would be done using SNF to avoid potential surrogate problems; however, a simulated fuel 
could be used for most experiments, and an SNF duplicate could be used to confirm that the surrogate is performing similarly to the SNF. Meticulous control over environmental conditions of the experiment is easier with unirradiated fuel.

The ANL drip tests have been running continuously for almost 10 years. This has the advantage over other short-term experiments in understanding long-term issues with SNF; however, they suffer from many of the same limitations as the Series 1, 2, and 3 tests. The use of EJ-13 water in the drip tests has resulted in the SNF being covered in clays because of high Si content of the water. In the Series 2 tests, the fuel, which was immersed in J-13 water, was covered with silica. The effect of this barrier on rates of reaction and neptunium behavior is unknown. The drip tests are also not at atmospheric oxygen levels. Low oxygen content will slow the rate of corrosion below what is expected in the repository and affect chemical potential and phase formation. Combined with a clay barrier, this gives results that are unreliable and cannot unambiguously determine radionuclide behavior. It is necessary to determine if these conditions are relevant to any of the proposed scenarios in the repository.

The four neptunium holdup mechanisms suggested by ANL still have not been narrowed down by current experimental data. The first mechanism [incomplete oxidation of $\mathrm{Np}(\mathrm{IV})$ to $\mathrm{Np}(\mathrm{V})$ ] cannot be dismissed because of experimental evidence of crystalline $\mathrm{NpO}_{2}$ in the $\mathrm{U}_{3} \mathrm{O}_{8}$ tests. However, it cannot explain trends in neptunium concentrations observed in both the Series 1, 2, and 3 tests and ANL drip tests, both of which have limitations. The second mechanism [co-precipitation of neptunium with U(VI) solid phases] can explain concentration changes in solution, and has been observed with studtite by two independent groups. However, the incorporation into the various forms of schoepite appears to be minor without the presence of counter ions but should, in theory, occur under repository conditions. Preliminary experiments in this area need to be expanded to provide the technical basis to support TSPA models. The third mechanism (sorption) is no different than the second mechanism in the models used in TSPA. The extent of sorption onto U(VI) solids, the waste package, or both have not been quantified. The fourth mechanism (ion exchange) may be minor because of the low concentration of neptunium. However, there is no experimental evidence to discount this mechanism.

The four potential mechanisms for holdup of neptunium suggested by Finch et al. ${ }^{(a)}$ need to be addressed in testing to determine the fate of neptunium in the repository. Any future waste-form testing must specifically attempt to unambiguously determine which of these mechanisms will be important under repository-relevant conditions. Past testing (Series 1, 2, and 3 tests and drip tests) have limited oxygen, which affects the kinetics, the oxidation states of uranium and neptunium, and the chemical potentials. The current dissolved concentration tests using $\mathrm{U}_{3} \mathrm{O}_{8}$ also do not have the same chemical potential as what is expected in the repository. Future experiments must be carefully designed and carried out so interpretation of the results unambiguously confirm or reject any or all of the potential mechanisms.

(a) RJ Finch and JA Fortner, Progress report. 


\subsection{References}

Andrews RW, TF Dale, JA McNeish. 1994. Total System Performance Assessment-1993: An evaluation of the potential Yucca Mountain Repository. INTERA, Inc., Las Vegas, NV.

Barner JO. 1984. Characterization of LWR Spent Fuel MCC-Approved Testing Material ATM-101. PNL-5109, Pacific Northwest Laboratory, Richland, WA.

Brooks DJ, and JA Corrado. 1984. Determination of Radionuclide Solubility in Groundwater for Assessment of High-Level Waste Isolation. U.S. Nuclear Regulatory Commission; Washington D.C.

Burns PC, RC Ewing, ML Miller. 1997. "Incorporation Mechanisms of Actinide Elements into the Structures of $\mathrm{U}^{6+}$ Phases Formed During the Oxidation of Spent Nuclear Fuel." J. Nucl. Mater. 245:1-9

Burns PC, RJ Finch, and DJ Wronkiewicz. 2001. Direct Investigations of the Immobilization of Radionuclides in the Alteration Phases of Spent Nuclear Fuel. DOE-EMSP Interim Report for Project Number 59960, renewed as 73691 (U.S. Department of Energy Environmental Management Science Programs, Washington D.C.).

CRWMS M\&O. 2000. Commercial Spent Nuclear Fuel Degradation in Unsaturated Drip Tests. WP-WP-99432.T. Las Vegas, NV

Czerwinski K, Y Severstre, W Rattray, C Sherman, M Vial, and D Reed. 2001. Progress Report, Chemical Speciation of Neptunium in Spent Fuel. DE-FG03-99SF21903, Massachusetts Institute of Technology, Cambridge, MA.

Efurd DW, W Runde, JC Banar, DR Janecky, JP Kaszuba, PD Palmer, FR Roensch, and CD Tait. 1998. "Neptunium and Plutonium Solubilities in a Yucca Mountain Groundwater." Environ. Sci. Tech. 32: 3893-3900.

Lemire RJ. 2001. Chemical Thermodynamics of Neptunium and Plutonium, OECD Nuclear Energy Agency, Elsevier, Amsterdam, The Netherlands.

McNamara BK, EC Buck, and BD Hanson. 2002. "Scientific Basis for Nuclear Waste Management XXVI.” In: Materials Research Society Annual Fall Meeting, December 2-6, 2002, Boston, MA.

Nitsche H, RC Gatti, EM Standifer, SC Lee, A Muller, T Prussin, and RS Deinhammer. 1992a. Measured Solubilities and Speciation of Neptunium, Plutonium, and Americium in Typical Groundwater (J-13) from the Yucca Mountain Region. Lawrence Berkeley Laboratory, Berkeley, CA.

Nitsche H, K Roberts, T Prussin, A Muller, K Beraft, D Keeney, SA Carpenter, and RC Gatti. $1992 \mathrm{~b}$. Measured Solubilities and Speciations from Oversaturated Experiments of Neptunium, Plutonium, and Americium in UE-25\#1 Well Water from the Yucca Mountain Site Characterization Program. Lawrence Berkeley Laboratory, Berkeley, CA. 
Rai D, and JL Ryan. 1985. "Neptunium(IV) Hydrous Oxide Solubility under Reducing and Carbonate Conditions." Inorg. Chem. 24(3): 247-251.

Wilson CN. 1987a. Results from NNWSI Series 1 Spent Fuel Leach Tests. HEDL-TME 84-30, Westinghouse Hanford Company, Richland, WA.

Wilson CN. 1987b. Results from Cycles 1 and 2 of NNWSI Series 2 Spent Fuel Dissolution Tests. HEDL-TME 85-22 Westinghouse Hanford Company, Richland, WA.

Wilson CN, and CJ Bruton. 1989. Studies on Spent Fuel Dissolution Behavior Under Yucca Mountain Repository Conditions. PNL-SA-16832, Pacific Northwest Laboratory, Richland, WA.

Wilson CN. 1990. Results from NNWSI Series 3 Spent Fuel Dissolution Tests. PNL-7170, Pacific Northwest Laboratory, Richland, WA. 


\section{Distribution}

No. of

Copies

\section{OFFSITE}

1 Argonne National Laboratory

9700 S. Cass Ave.

Argonne, Illinois 60439

Attn: JC Cunnane

1 Sandia National Laboratory

1515 Eubank SE

Albuquerque, NM 87123

Attn: PV Brady

7 Bechtel SAIC Company, LLC 1180 Town Center Drive

Las Vegas, Nevada 89144

Attn: Howard Adkins

Yueting Chen (2)

Eric Siegmann

Christine Stockman

Terry Steinborn

Tom Thornton
No. of

Copies

\section{ONSITE}

34 Pacific Northwest National Laboratory

J. Abrefah

P7-27

B. O. Barnes

P8-50

E. C. Buck

$\mathrm{P} 7-27$

J. I. Friese (6)

P7-22

B. D. Hanson (20)

$\mathrm{P} 7-27$

J. P. Icenhower

K6-81

B. P. McGrail

K6-81

B. K. McNamara

P7-25 